American University Washington College of Law

Digital Commons @ American University Washington College of

Law

Articles in Law Reviews \& Other Academic Journals

Scholarship \& Research

2018

Innovation and Tradition: A Survey of Intellectual Property and Technology Legal Clinics

Victoria Phillips

Follow this and additional works at: https://digitalcommons.wcl.american.edu/facsch_lawrev 


\title{
INNOVATION AND TRADITION: A SURVEY OF INTELLECTUAL PROPERTY AND TECHNOLOGY LEGAL CLINICS
}

\author{
Cynthia L. Dahl and Victoria F. Phillips*
}

For artists, nonprofits, community organizations and small-business clients of limited means, securing intellectual property (IP) rights and getting counseling involving patent, copyright and trademark law are critical to their success and growth. These clients need expert IP and technology legal assistance, but very often cannot afford services in the legal marketplace. In addition, legal services and state bar pro bono programs have generally been ill-equipped to assist in these more specialized areas. An expanding community of IP and Technology clinics has emerged across the country to meet these needs. But while law review articles have described and examined other sectors of clinical legal education, there has not been an article to date that examines the rise and the role of such clinics. This is an important need to fill. With student and client and law firm demand for IP and Technology clinics, law schools want information about existing programs, and existing programs want information about the innovations of other clinics and collaboration opportunities. In addition, the traditional clinical community wants to ensure that these new programs build on the strengths of the original founding clinics. This article distills the results of a comprehensive survey of seventy-two distinct IP and Technology clinics into themes that analyze the focus and aspirations of this new clinical community. It takes stock of what $I P$ and Technology clinics were founded to accomplish, how and what they are teaching students, and what clients and missions drive them. It highlights some individual innovations to inspire the community to continue to grow and change. It concludes by assessing what these clinics accomplish, how they are faring on these goals and the role they may play in the future of clinical legal education and experiential learning more generally.

* Cynthia Dahl is Practice Professor of Law and the Director of the Detkin Intellectual Property and Technology Legal Clinic at the University of Pennsylvania Law School. Victoria Phillips is Professor of Practice of Law and the Director of the Glushko-Samuelson Intellectual Property Law Clinic at American University Washington College of Law. The authors would like to thank Raridy Hertz, Jodi Balsam, Meg Reuter, Alina Ball, Manoj Viswanathan, and Gillian Dutton for their invaluable feedback on an early version of the article at the NYU Clinical Law Review Writers' Workshop and Pratik Agarwal, Jekka Garner and Joseph Kerins for their research support. We also would like to acknowledge and thank all our colleagues who spent time answering our survey and providing the data on which this paper is based. We are in awe of your devotion to your students, your creative programs, and the tremendous help and support you provide to your communities. 


\section{INTRODUCTION}

Consider the following situations:

- The owner of a small business selling products for boating enthusiasts receives an overreaching cease and desist letter from an international fashion company demanding she pay excessive damages for trademark infringement;

- Documentary film makers exploring the urban civil rights rebellions of the 1960's need to incorporate some network news footage into their film to provide historical context and critique for the story;

- A researcher discovers a groundbreaking method to use biomarkers to identify cancer;

- A nonprofit matching prisoners with outside musicians to compose songs and build fellowship wants to release an album of jointly written and produced music;

- Juvenile justice advocates want to expose the harms potentially involved in the use of electronic monitoring for juveniles on intensive probation.

All need expert intellectual property (IP) and technology-related legal assistance, yet cannot afford services in the legal marketplace. In addition, traditional legal service agencies and state bar pro bono programs are usually unequipped to assist in these specialized areas. ${ }^{1}$ Luckily, the business owner fought back against the trademark bullying and has since expanded her business. ${ }^{2}$ The filmmakers released an award-winning film using clips under the fair use provision of the copyright law. ${ }^{3}$ The researcher was granted a patent on his method. ${ }^{4}$ The

1 Specialized IP and technology-related expertise has not been traditionally available through direct legal services organizations. Only recently has the American Bar Association started to provide material and information on specialized pro bono IP legal assistance including Volunteer Lawyers for the Arts legal referral organizations for the creative community and the new IP clinic community. See What is Legal Aid?, Legal Services CorPORATION https://www.lsc.gov/what-legal-aid (last visited Aug. 2, 2018) (describing services provided by organizations as primarily family, consumer, housing, employment and other legal issues that affect low-income individuals and families); Am. Bar Ass'n: Section of Intellectual Property Law, Pro Bono IPL Resources in the United States, AM. BAR Ass'N, https://www.americanbar.org/groups/intellectual_property_law/resources/probonostates.html (last visited Aug. 2, 2018).

2 Dave Gallagher, Bellingham's Nautigirl Wins Key Trademark Case, The Bellingham Heraid (Nov. 2, 2015, 5:18 PM), http://www.bellinghamherald.com/news/local/ article41996670.html.

3 See Bongionno Productions, Revolution '67, http://www.bongiornoproductions. com/REVOLUTION_67/REVOLUTION_67.html (last visited Feb. 5, 2018); Copyright Law Guide, Am. Univ. Wash. Coll. of Law Glushro-Samuelson IP Clinic, hittps:// ipclinic.org/clients/rights-acquisition-and-counseling-copyright/ (last visited Feb 5, 2018).

4 See Rob Burgess, Notre Dame Law School Clinic Secures Disease Detection Patent, THE INDIANA LAwYER (Jan. 16. 2018), https://www.theindianalawyer.com/articles/45888notre-dame-law-school-clinic-secures-disease-detection-patent. 
nonprofit is on the way to recording their album. ${ }^{5}$ The advocates' recently-released report suggests that the invasiveness of electronic monitoring may worsen the very problems that juvenile courts try to remedy. ${ }^{6}$ In each case, law school IP and technology legal assistance clinics ("IP/T clinics") provided the specialized legal counsel that these clients needed, filling gaps in the market for legal services. With their help, these clients were able to advance their work and meet their goals.

Across the country, the number of IP/T clinics is on the rise. Every year news reports announce more schools adding such clinics to their offerings. ${ }^{7}$ The most recent survey from the Center for the Study of Applied Legal Education (CSALE) illustrates that Transactional, Entrepreneurship/Small Business and IP clinics are among the fastest growing segment of the clinic community. ${ }^{8}$ However, while some scholars have already examined the community development ${ }^{9}$ and entrepreneurial/start-up ${ }^{10}$ sectors of the transactional clinical community, there has yet to be an analysis of the rise and role of the newest branch of the law school clinic family: IP/T clinics. As the numbers of these new clinics continue to grow, it is helpful to take stock of what these clinics were founded to accomplish, how and what they are teaching students, and how they fit into the larger clinical community. This article aims to fill that gap. We have three purposes. First,

5 See Samantha Melamed, After a Decade Without Music, Pa. Prison Inmates Play Again, THE INQUIRER (June 3, 2017), https://www.apnews.com/63b9eb7248344Oe4b64b8f 37 aa1f0750.

6 See Catherine Crump, Kate Weisburd, and Christina Koningisor, Electronic Monitoring Isn't Kid-friendly, SACRAMENTo BEE (July 20, 2017, 1:54 PM), http://www.sacbee.com/ opinion/op-ed/soapbox/article162572678.html.

7 See, e.g., Shawn Annarelli, Penn State to Open Intellectual Property Clinic, CENTRE DAIL Y TIMES (Feb. 12, 2016, 4:21 PM), http://www.centredaily.com/news/business/article60081176.html; Curt Woodward, Berkman Center Lawyer to Run New Cyberlaw Clinic for BU, MIT Students, THE Boston Globe (Mar. 15, 2016), http://www.betaboston.com/ news/2016/03/15/berkman-center-lawyer-to-run-new-cyberlaw-clinic-for-bu-mit-students/; Univ. OF Cincinnati Coll. of Law, Patent and Trademark Clinic, https:// www.law.uc.edu/clinics/ptc (last visited Aug. 2, 2018).

8 See Robert R. Kuehn \& David A. Santacroce, 2016-17 Survey of Applied Legal Education, CTR. For THE STUdy OF APpled Legal Educ. 8-9 (2017), http://www.csale.org/ files/Report_on_2016-17_CSALE_Survey.pdf; Susan R. Jones \& Jacqueline Lainez, Enriching the Law School Curriculum: The Rise of Transactional Legal Clinics in U.S. Law Schools, 43 WASH U. J.L. \& POL'y 85, 86 (2014) ("[T]ransactional legal clinics have grown exponentially and have manifested in increasingly diverse transactional specialties ...").

9 See, e.g., Susan R. Jones, Promoting Social and Economic Justice through Interdisciplinary Work, 14 WASH U. J.L \& PoL'y 249, 259 (2004) (noting that "majority of transactional legal clinics" arose in late 1970s and early 1980s following "critique of the traditional model of public interest lawyering that focused on litigation").

10 See, e.g., Anthony J. Luppino, Minding More than Our Own Business: Educating Entrepreneurial Lawyers Through Law School-Business School Collaborations, 30 W. NEw ENG. L. Rev. 151, 151-152 (2008). 
we present a "state of the clinic" description of the IP/T clinic community, which is helpful to set the stage for understanding what these clinics are trying to accomplish. By discussing subject matter, work tasks, and missions, we are able to highlight both similarities and differences among the clinics themselves and between these IP/T clinics and other parts of the clinical community. We then contextualize this information and propose needs and forces that have driven the recent meteoric growth of these clinics.

Second, this article uses the information we have gathered to detail some individual innovations in the IP/T community of clinics. By describing this new clinic landscape, we aim to benefit both current members of the IP/T clinic community, as well as others. Some of the innovations we describe might carry over to other kinds of clinics, and by relaying information about clinic projects and design, we hope to encourage both individual clinic growth and cross-clinic collaboration.

Lastly, by describing these clinics so closely, we hope to help all clinicians better understand the underlying goals, contributions, pedagogy and loyalty to the clinical tradition and public interest mission embodied in IP/T clinics. As so many new clinics, especially those dealing with transactional business areas of law come online, some commentators are expressing concern about the future of clinical education, both with regard to its pedagogical rigor and its underlying social justice values. ${ }^{11}$ However, our data presents a more complicated (and we think reassuring) picture about how IP/T clinics are just a further and natural extension of what is unique and transformative about clinical legal education. In addition, there is evidence in the data demonstrating that this new group of clinics has inspired both governmental and private sector efforts to increase their commitment to pro bono service in this field.

This paper is based on information that we gathered through surveying and interviewing directors from seventy clinics in the U.S. and two in Canada. In contextualizing and relaying the results, we have divided the reporting and discussion into sections. Section II gives proper background for the rest of the article in substantiating and explaining the recent growth of IP/T clinics and explaining why the exercise of gathering information and reflecting on it now is important. Section III conveys and explains some of the survey results, with a focus on some surprising ways that IP/T clinics are similar or different from other kinds of clinics. After a quick discussion of methodology,

11 See Sameer M. Ashar, Law Clinics and Collective Mobilization, 14 Clin. L. Rev. 355, 356 (2008); See John O. Calmore, "Chasing the Wind": Pursuing Social Justice, Overcoming Legal Mis-education, and Engaging in Professional Re-socialization, 37 LoY. L.A. L. Rev. 1167, 1169-70 (2004). 
it gives a snapshot of the work these clinics handle, as well as the clients they choose to serve and the work they accomplish as related to their missions. Section III also relays some of the more interesting innovations developed by this new line of clinics. The concluding Section IV fits IP/T clinics into the larger clinical community. It discusses what IP/T clinics set out to accomplish, whether they are succeeding in meeting the need that created them, whether they challenge the old clinical model or not, and what role they might play in the future of clinical and experiential legal education.

\section{The Emerging IP/T Clinical Community}

There is no doubt that there has been an impressive uptick in the creation of new IP/T law school clinics over the past decade or so. In this section we analyze our survey results to document this growth and to help to unearth the various forces inside and outside the law school academy fueling these developments.

\section{A. The IP/T Clinical Community Has Experienced Extraordinary Growth Over the Past Two Decades}

Our survey results substantiate that although IP/T clinics began roughly two decades ago, their growth has gained significant momentum in the last several years. ${ }^{12}$ In addition, the CSALE survey in 2016-17 reported that over half of the nation's law schools now offer some kind of transactional and small business/entrepreneurship clinic, and nearly a quarter of them offer a standalone IP clinic. ${ }^{13}$ This growth has been part of a trend emerging over the past decade. The prior three CSALE surveys done in 2007-08, 2010-11 and 2013-14 similarly reveal that IP has been one of the fastest growing substantive areas of focus for new law school clinics. ${ }^{14}$

12 Forty-two IP/T clinics have been founded since 2010, whereas twenty-two were founded between 1999 and 2009.

13 See Kuehn \& Santacroce, supra note 8, at 8-9.

14 See Robert R. Kuehn \& David A. Santacroce, 2013-14 Survey of Applied Legal Education, Ctr For The Study of Applied Legal Educ. 7-8 (2014), http:// www.csale.org/files/Report_on_2013-14_CSALE_Survey.pdf (demonstrating that clinics focusing on immigration, transactional law, and IP reported the largest percent increase between 2011 and 2014 surveys; however, the surveys have not included a specific technology [as separated out from IP] clinical category). 


\section{Growth of IP and Technology Clinics}

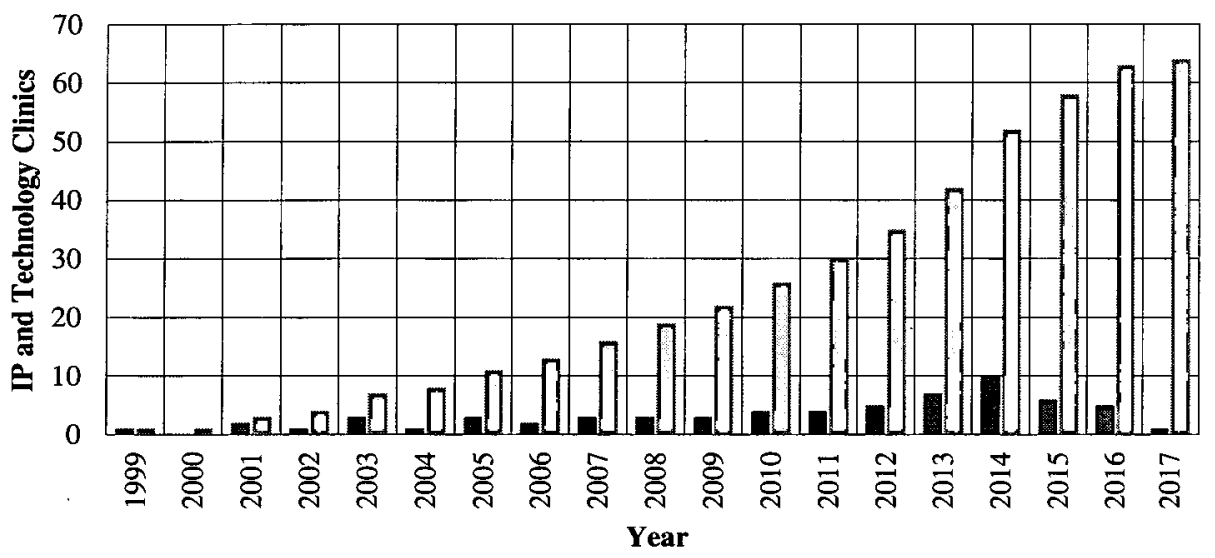

\# \# Clinics Opened a Cumulative \# of Clinics

Our survey responses indicate that the law school IP/T clinic community has evolved in response to calls for a new kind of clinic to address heretofore unmet needs of the local and law school community. ${ }^{15}$ For example, some clinics were created to add a new kind of legal support to local entrepreneurs. Some clinics responded to student or doctrinal faculty demand for legal training involving IP and technology subject matter. Additionally, many clinics were founded to provide experiential and training opportunities for students in transactional rather than litigation practice.

In other instances, funders from industry or interested alumni of the law schools sparked a number of IP/T clinics to give students the training these funders believed necessary. Other clinics were funded by activists to bolster an emerging consumer rights counter-movement, extending the voice and capacity of advocates guarding the criti-

15 Many of the IP/T clinics fall into this category, but some notable mission statements follow. Indiana University Bloomington Haurer School of Law IP Law Clinic says they were founded to "fill the gap in IP services experienced by those of limited financial means until they can afford to pay for IP services"; California Western School of Law's New Media Rights Clinic was founded as a "non-profit program to provide IP, Internet, and Communications law expertise to underserved creators, entrepreneurs, and internet users." The University of Missouri School of Law's Entrepreneurship Legal Clinic was founded to "[f]ill the void for available, affordable startup legal services in Mid-Missouri, while most importantly, giving [University of Missouri] law students the opportunity to receive handson experience representing entrepreneurs and innovators." Finally Yale University Law School's Media Freedom and Information Access Clinic states that they were "founded by four law students who saw two unmet needs: (1) opportunities for students to engage in work on tech, privacy, free speech, media law national security, and surveillance issues, and (2) legal support for online and non-traditional journalists, online news outlets, investigative non-profits, and public interest organizations that are working on issues of technology, national security, law enforcement, and other matters of significant public concern." 
cal balance in IP between protecting creative endeavors and promoting access to information and creative work. ${ }^{16}$ Some of these clinics were created as an initiative of newly emerging public interest IP/T organizations in order to further the organization's work. Most recently, many clinics were initiated to take advantage of the opportunity to participate in the United States Patent and Trademark Office's (USPTO) student practice program. ${ }^{17}$

Law school clinics have been facing an increasing battle for student attention against other experiential offerings such as externships, simulation courses and practicums. Law school journals, programs, centers, jobs and pro bono opportunities also vie for student attention. IP/T clinics, however, have proven extremely popular and are often oversubscribed, as they not only address previously unmet needs, but also open up a clinical opportunity to an entirely new segment of the law student population.

\section{B. A Variety of Forces from Inside and Outside the Academy Led to the Growth of this New Clinic Community}

A variety of forces from inside and outside the legal academy contributed to the growth of the IP/T clinical community. Survey responses to more targeted questions about clinic founding missions illustrate these various forces.

\section{Legal Education Has Increasingly Embraced Experiential Learning}

Inside the academy, the most notable driving force in the growth of clinics overall has been the movement towards an increasing emphasis on experiential learning in the law school curriculum. This sea change was chronicled first in the 1992 MacCrate Report ${ }^{18}$ and then in the 2007 Carnegie Report ${ }^{19}$ on the state of legal education. These landmark studies highlighted the need for and the importance of the

16 The clinics funded by Berkeley Law IP scholar Pamela Samuelson and her husband Robert Glushko fall into this category.

17 See Act of Dec. 16, 2014, Pub. L. No. 113-227, 128 Stat. 2115 (USPTO Law School Clinic Certification Program); see generally Jennifer Fan, Institutionalizing the USPTO Law School Clinic Certification Program for Transactional Law Clinics, 19 LewIs \& Clark L. Rev. 327 (2015).

18 ABA Section of Legal Education and Admissions to the Bar, Legal Education and Professional Development - An Educational Continuum (Report of the Task Force on Law Schools and the Profession: Narrowing the Gap) (1992) (hereafter cited as "MacCrate Report").

19 William M. Sullivan, Anne Colby, Judith Welch Wegner, Lloyd Bond \& Lee S. Shulman, Educating Lawyers: Preparation for the Profession of Law (Carnegie Foundation for the Advancement of Teaching 2007) (hereafter cited as "Carnegie Report"). 
introduction of hands-on learning in the law school curriculum. ${ }^{20}$ The reports both agreed that the best legal education should integrate doctrine with skills training and foster the development of each student's professional identity. The most recent ABA standards for legal education are a culmination of this evolution in rethinking law school pedagogy. These requirements now mandate six experiential credit hours for all graduates of its accredited law schools. ${ }^{21}$

These calls for more experiential legal education offerings directly increased interest and investment in in-house live client law school clinics across the board, not only in the IP/T space. However, as the community of clinics grew, there was also a corresponding development of more specialty subject matter clinics to address emerging needs for access to justice and pro bono advocacy across practice areas. Some early examples of these specialized clinics included those focused on environmental law and international human rights. ${ }^{22}$ More recently, specialized immigration clinics have developed to meet growing needs in that area. Some of the earliest IP/T clinics were founded based on a similar emerging need for consumer rights policy advocacy and impact litigation in the IP/T field. ${ }^{23}$ At the same time, a new crop of law school-based clinics taking on non-litigation and transactional work also began to evolve to assist low-income communities and non-profits with business development and assistance. ${ }^{24}$ More recently, transactional clinics have increasingly been focused on entrepreneurship and innovation, mirroring the growing interest in these areas at business schools and other programs across the university community. Some of these clinics also started to take on routine intellectual property work and IP rights acquisition activities on behalf of their clients. IP/T clinics are a natural outgrowth of these clinics, as student interest and community need in this area began to outpace the

20 See Carnegie Report, id., at 6 (noting that "most law schools give only casual attention to teaching students how to use legal thinking in the complexity of actual law practice. Unlike other professional education, most notably medical school, legal education typically pays relatively little attention to direct training in professional practice. The result is to prolong and reinforce the habits of thinking like a student rather than an apprentice practitioner, conveying the impression that lawyers are more like competitive scholars than attorneys engaged with the problems of clients.").

21 See aba Section on Legal Educ. and Admissions to the Bar, ABA Standards and Rules of Procedure for Approval of Law Schools 2015-2016, 16-17 ("One or more experiential course(s) totaling at least six credit hours. An experiential course must be a simulation course, a law clinic, or a field placement.").

22 See Richard Wilson, The Global Evolution of Clinical Legal Education: MORE THAN A Method (2018); Deena R. Hurwitz, Lawyering for Justice and the Inevitability of International Human Rights Clinics, 28 YALE J. INT'L L. 505, 524 (2003).

23 See Christine Haight Farley, et. al., Clinical Legal Education and the Public Interest in Intellectual Property Law, 52 ST. Lous U. L.J. 735 (2008).

24 See Jones \& Lainez, supra note 8, at 86. 
amount of work that more general transactional clinics could provide.

\section{The New Internet Economy Demands Access to Specialized IP/T Legal Assistance}

At the same time these trends were sweeping across campuses, powerful changes outside the academy were helping to spur the boom in the IP/T clinic community as well. Most significant was the migration to digital technology and the development and rise of a new internet-based economy. Born in the 1990's, the new economy ushered in a greater need for a more specialized focus on and increased expertise in intellectual property and technology-related legal services. These legal needs were not only necessary for corporate clients and those with access to private law firms, but also vital for small businesses, start-up ventures, non-profit entities and for the community of creators, inventors and scholars of more limited means. ${ }^{25}$ Many of our survey responses explicitly note the founding impetus for their clinics was to provide IP and business law advice to early stage companies, community-based organizations and non-profit entities not able to obtain or afford those specialized legal services in the marketplace. ${ }^{26}$ The emergence of innovative new corporate structures such as social benefit corporations and B-Corp status also exacerbated the need for expert yet low cost IP/T legal services.

Our data demonstrates that IP/T clinics have been founded in this new economy to serve a variety of missions, some of which align with traditional notions of social justice, and others of which might be social and public interest missions of a different sort. It is a continuing debate in the clinic community whether pursuing social justice is a necessary piece of the clinical fabric at all. ${ }^{27}$ This new community of

25 See Anthony Reese, Copyright and Trademark Law and Public Interest Lawyering, 2 UC IRvine L. REV. 911, 918 (2012) ("Likewise, a struggling small business owner who finds her trademark being infringed but cannot afford a lawyer may end up not being compensated for any damages she has suffered and may not be able to enjoin a third party's continuing infringing use of her trademark and the continued harm that use causes to her business by confusing consumers.")

26 The University of Cincinnati College of Law's Patent and Trademark Clinic seeks to "[a]ddress legal needs of local businesses which could not otherwise afford it"; the University of New Hampshire School of Law's IP and Transaction Clinic "is designed with the dual purposes of serving the community/meeting legal needs for those who lack the means to obtain legal counsel in the matters we take on and student education"; the Washington University in St. Louis School of Law's Entrepreneurship and IP Law Clinic has as part of their mission the idea of "[e]ngaging students in addressing the legal needs of disadvantaged individuals, nonprofit organizations, small businesses and government agencies;" and the University of California Los Angeles School of Law's Trademark Clinic seeks to "Provide pro bono services to low income [for profits] (below \$150,000) and 501(c)3[s]." See also supra note 15.

27 See Robert D. Dinerstein, Clinical Scholarship and the Justice Mission, 40 CLEV. ST. 
clinics is engaged in activity supporting healthy entrepreneurial ecosystems in local communities. Students advocate for laws that protect individual entrepreneurs and small under-resourced companies from overzealous IP owners and help early stage technologies find a way to get to market. These activities are steeped in notions of the public interest. The breadth of the client base in these clinics also leads to a varied and multidimensional legal practice from purely transactional to advocacy undertaken through education, policy and litigation. Therefore, IP/T clinics may define public interest missions in slightly different ways than other parts of the clinical community, given that some of their client base consists of small for-profit entities. These clinics see their role as filling the void for legal assistance for these early stage or community entities where the traditional legal marketplace is not accessible. ${ }^{28}$ For others, helping the under-resourced may be one factor, but pedagogy, exposure to the field, and setting people up for success in the workplace are also worthy goals. ${ }^{29}$

What emerges from the survey data and conclusions that follow is that IP/T clinics established over the past two decades have been pioneers in long overdue efforts to open channels for pro-bono IP/T-related legal services for underserved communities of creators, businesses, non-profits and start-up entities. These clinics are filling a

L. Rev. 469, 469 (1992) (noting that the relationship between clinical programs and the justice mission of American law schools is so clear as to be self-evident. Many live-client clinical programs represent indigent persons in criminal cases or in numerous kinds of civil cases, such as domestic violence, landlord/tenant, public benefits, and social security disability matters, where (in)justice themes predominate); Gary Bellow \& Earl Johnson, Reflections on the University of Southern California Clinical Semester, 44 S. CAL. L. REv. 664, 670-71 (1971) (observing that it is questionable whether service to the unrepresented, despite the enormous need, can be a major function of clinical programs); see also Praveen Kosuri, Clinical Legal Education at a Generational Crossroads: X Marks the Spot, 17 CLIN. L. REV. 205, 220 (2010) (noting that "[t]ransactional clinics are. . less tethered to the past because [they] did not emerge from the fervor of the civil rights era); Minna J. Kotkin \& Dean Hill Rivkin, Clinical Legal Education at a Generational Crossroads: Reflections from Two Boomers, 17 Clin. L. Rev. 197, 198 (2010) (noting that clinical legal education is rooted in notions of service to underserved clients and communities).

28 See Gillian K. Hadfield, The Price of Law: How Much the Market for Lawyers Distorts the Justice System, 98 MicH. L. REv. 953, 998 (2000) (using an economic analysis to explain how individuals are priced out of access to legal services, resulting in a distorted system that primarily serves economic interests and does not fulfill justice interests); Anne Jurgens, Valuing Small Firm and Solo Law Practice: Models for Expanding Service to Middle-Income Clients, 39 William Mitchell L. Rev. 80, 103 (2012 (discussing the lack of IP practitioners with middle-income clients); see also Lynnise E. Pantin, The Economic Justice Imperative for Transactional Law Clinics, 62 VILL. L. REv. 175, 206 (2017) ("The clinic can empower students to become highly effective business law advisers by developing their arsenal of substantive knowledge and lawyering skills, empower clients by providing muchneeded transactional legal assistance and community education that will promote and support innovation and entrepreneurship, and contribute meaningfully to the entrepreneurship and innovation ecosystem in the clinic's area.").

29 See infra Part II.B.3 for an in depth discussion of clinic missions. 
void. However, these clinics have also been catalysts for change across the private bar. Historically, pro bono legal assistance and expertise in the field of IP and technology law has been largely unavailable through legal services entities, state and local bar association pro bono programs and general practice law school clinics. Until very recently, pro bono IP and technology law representation was also rarely provided by private law firms. This new community of clinics has most recently inspired both government and private sector efforts to encourage and foster more pro bono activity in IP and technology practice. The most obvious example is the USPTO Law School Clinic Certification Program, ${ }^{30}$ discussed at length in Section IV, below. However, many law firms are also starting programs to provide IP assistance to these underserved inventors and ventures. ${ }^{31}$ And the U.S. government through the 2011 Leahy-Smith America Invents Act (AIA) encouraged the private IP bar to direct their pro bono efforts more to this area by directing the USPTO to "work with and support local intellectual property law associations across the country in the establishment of pro bono programs designed to assist financially under-resourced independent inventors and small businesses. ${ }^{32}$ With an expansion to the effort in 2014 through Presidential Executive Action, the private bar is now providing assistance through Patent Pro Bono Programs in 47 states. ${ }^{33}$

Access to IP and technology lawyering expertise is needed across all sectors of the economy and is a critical component of community economic development, launching successful entrepreneurial ventures, and serving the creative economy. In such respects, the mission of many of these clinics is rooted in access to justice goals.

\section{The Survey Data}

This section first provides a brief summary of our survey methodology and then presents some of the most salient results of the survey, with our commentary. We gathered much more information than we can discuss in this article. ${ }^{34}$ However, given the article's focus, we will discuss the survey information that best describes IP/T clinics' place

30 See Act of Dec. 16, 2014, Pub. L. No. 113-227, 128 Stat. 2115 (USPTO Law School Clinic Certification Program); see generally Fan, supra note 17.

31 See e.g., Ballard Academy for Student Entrepreneurs (BASE) Program, Ballard SPAHR LLP, http://www.ballardspahr.com/pro_bono/base.aspx (last visited Aug. 2, 2018).

32 See Leahy-Smith America Invents Act, 35 U.S.C. \$ 32 (2011); Pro Bono Programs, U.S. PATENT AND TRADEMARK OFFICE, https://www.uspto.gov/patent/laws-and-regulations/america-invents-act-aia/programs (last visited Aug. 2, 2018).

33 See Grant Corboy, Pro Bono Program, U.S. Patent and Trademark Office, https://www.uspto.gov/patents-getting-started/using-legal-services/pro-bono/pro-bono-pro gram (last visited Aug. 2, 2018).

34 Complete survey data on file with authors. 
within the larger clinical community and relays some of their best innovations.

\section{A. Methodology}

\section{Information Gathering}

To compile the survey data, we distributed a sixty-one question electronic survey using Qualtrics software asking clinic directors to describe the following aspects of their clinic: i) the kinds of work handled; ii) the types of clients; iii) the topical subject matters of focus; and iv) their clinic's structure and logistics. ${ }^{35}$ We sent the survey invitation to: i) clinics participating in the USPTO Law School Certification Program; ii) the clinics on four listservs with a high circulation to the IP/T clinic population; ${ }^{36}$ iii) clinics attending the Intellectual Property Working Group of the AALS Clinical Conference in 2016; iv) clinics we knew to be missing from the list; v) clinics we found through internet searches on the keywords "intellectual property clinic" and "technology clinic"; and vi) clinics identified by the survey group in response to the question "what other IP Clinics in your state/area should we be sure to contact?" As we identified additional clinics during this first phase of our information gathering, we continued to solicit answers. We collected initial survey results between March and June, 2016.

During the second phase of the information gathering, between April and July, 2016, we reviewed all survey responses and followed up with emails or telephone interviews to clarify answers as necessary. We then updated our final survey results in a third phase of information gathering: i) in August, 2017 we extended an opportunity to all previously surveyed clinics to update their survey results; and ii) in August, 2017 and again in February, 2018, we sent a survey invitation out to clinic directors of all new clinics that had opened since July, 2016. Between new surveys, updates to old surveys, and comments we received from clinics that reviewed our drafts, the information was last updated in September, 2018.

\section{Parameters}

We intended to concentrate our research on the specific subsection of the clinical community most focused on IP and technology law.

35 See id.

36 These email lists included: i) a list run out of Harvard University School of Law's Berkman Klein Center for Internet and Society, composed of mostly policy-based IP/T clinics; ii) a listserv for transactional clinics managed by the Kauffman Foundation; iii) a listserv for IP/T clinics managed by American University Washington College of Law; and iv) a general listserv for all clinic faculty managed by the Washburn University School of Law. 
Therefore, we had to set careful boundaries to capture this niche of the clinical community. Accordingly, we only gathered information from: i) live-client clinics (excluding simulation courses); ii) without regard to the tenure status or title of the primary instructor (thus including courses primarily taught by part-time adjuncts); and iii) where either a) $80 \%$ or more of the clinic's live client work involved IP or technology law subject matter or b) if less than $80 \%$ of the live client work focused on IP or technology law, the clinic director nonetheless considered the clinic "primarily an IP/Technology Clinic." We did not distinguish on the basis of whether the clinics we surveyed were transactional clinics.

These parameters likely excluded most entrepreneurship and community development clinics that primarily focus on corporate or other legal work, yet deliver some IP counseling for clients when necessary. However, because of our savings clause that allowed clinics to self-identify as "primarily an IP/Technology Clinic," some entrepreneurship and community development clinics are in fact included in our results. We thought this was appropriate, since although there is variation among our sample in how much IP or technology work each clinic handles, our goal was to monitor the status and progress of all clinics that consider themselves foremost a member of the group of IP/Technology clinical community.

The parameters may have also excluded some clinics that focus on policy work in a related technology area, for example communications law or access to information and privacy concerns. There is a deep kinship but not necessarily complete overlap between clinics that handle traditional "IP" issues and those that are more broadly defined as "technology" clinics. Although the authors consider clinics focusing on purely technology related topics as welcome members of the IP/T clinical community, we left it up to the clinical directors to decide where they belonged. Some clinics that do policy work in these and other areas are in fact represented in our survey results, but it is possible that some of these clinics exited out after the first few answers depending on how clinical directors decided to characterize their work.

Of course, some members of our survey group may also be included in other groups that have already been studied. For example, many of the surveyed clinics can also be classified as transactional clinics, a class of clinic that also includes entrepreneurship clinics and community development clinics. However, our sample is unique because it looks at a set of clinics that specialize in the particular subject matters of intellectual property or technology law. Therefore, we studied clinics that handle policy work, clinics that engage in transac- 
tional law or litigation, clinics that engage in rights acquisition, and clinics that do a combination of two or even all three areas. This particular community has thus far never been studied.

We collected surveys from 90 distinct clinics from 78 schools. (We considered a clinic "distinct" from another if students could not enroll in the two clinics at the same time.) Of the 90 clinics that took the survey, 18 exited out after the first few questions because they did not self-identify as "primarily an IP/Technology Clinic" under our definition. Therefore, we collected survey results from 72 clinics that were our target demographic. ${ }^{37}$

\section{Limitations}

Our information reflects the accuracy and completeness of the data available at the times we distributed the survey and provided to us from the clinics that we canvassed. ${ }^{38}$ In addition, although we took pains to craft a survey that would provide useful information, we realize the responses may be skewed for at least a few reasons we can already identify. First, we asked respondents to estimate for i) types of work they handle and for ii) subject matters they handle in their clinics, what the "percentage. . of the whole" was for each. We did not clarify if we wanted respondents to interpret "the whole" as the number of total matters, number of student hours spent on the work/ subject matter, or total number of students in the clinic that handled that type of work/subject matter. Second, we asked faculty to answer using a "representative period" of their choosing, and to estimate their answers. And finally, by choosing to include some entrepreneurship or community development clinics that do less than $80 \%$ IP work, questions that ask about the prevalence of IP subject matter in the clinic reported lower averages overall than if we had only included clinics that did $100 \%$ IP or technology law work.

We tolerated some inexactness in our methods, both for practical reasons and because of the goal of the survey. Since our survey group consisted of clinics of different ages, and because clinics can change over time, leaving the time-frame for reported information open to interpretation we thought was appropriate. Asking for information over several years wasn't possible for new clinics, and asking for infor-

37 Since one clinic director answered with one survey to cover three clinics and another clinic director answered with one survey to cover two clinics, there were 69 independent results. Therefore, so as not to overstate the results, the rest of the paper will refer to a sample size of 69 . The 72 clinics that provided answers to our survey, the few clinics for which we could not gather information, and the clinics that we know are soon to join the community are all listed in Appendix A.

38 We mention some clinics more than others, which reflects at least in part the completeness of the information we received in the essay portions of the survey. 
mation over only the past year might not accurately reflect the overall goals of older clinics because of anomalies or recent experiments. We were also aware that we were asking much from busy people to answer a sixty-one question survey, so we allowed people to estimate, although we did ask that they compile an accurate list of clients and work before they turned to answering the questions. Finally, although allowing respondents to interpret the questions and estimate their answers probably injected some bias into our results, we did not think that was necessarily at odds with our purposes. Given that the goal of this survey was to gather a summary snapshot of the community, we wanted to capture both accurate information and also intentions. If the results are slightly biased toward what a faculty member hopes her clinic is accomplishing, that is still valuable information, and represents where the community is likely headed.

There is certainly opportunity for further data gathering and studies on this community, which could prove the fodder for future papers. Meanwhile, the results from this study are illuminating.

\section{B. Results}

The survey results tell a rich story of the work, clients, missions and innovations of the IP/T clinic community. From the stories and data, we have been able to pull generalizations that show how this community is similar to the rest of the clinical community, and also different in some predictable but also some surprising ways.

1. Subject matter: Although most IP/T clinics do handle a large percentage of IP work, their subject matter is often much broader than that.

\section{Topics of LAw AdDressed ${ }^{39}$}

\begin{tabular}{|c|c|c|c|c|c|}
\hline & Minimum & Maximum & Mean & $\begin{array}{l}\text { Standard } \\
\text { Deviation }\end{array}$ & Count \\
\hline $\begin{array}{l}\text { At least one of: Patent; } \\
\text { Copyright (not DMCA); TM; } \\
\text { Trade Secret }\end{array}$ & 15.00 & 100.00 & 75.22 & 25.13 & 64 \\
\hline Privacy or data protection & 0.00 & 100.00 & 20.76 & 22.35 & 37 \\
\hline $\begin{array}{l}\text { Related torts (e.g. defamation, } \\
\text { rights of publicity, rights of } \\
\text { privacy }\end{array}$ & 0.00 & 50.00 & 10.68 & 8.98 & 28 \\
\hline Other & 0.00 & 100.00 & 32.77 & 26.46 & 26 \\
\hline $\begin{array}{l}\text { Legislative or regulatory issues } \\
\text { (e.g. DMCA, FCC, FTC) }\end{array}$ & 0.00 & 100.00 & 20.73 & 25.45 & 26 \\
\hline
\end{tabular}

39 The values in the columns of data add nuance and validate the conclusions discussed in the text of the paper. The "Minimum" column shows how much work involving a certain 
Not surprisingly, about $93 \%$ of IP/T clinics report that they do some work $^{40}$ related to the core IP subjects of patent, copyright, trademark, and trade secrets. ${ }^{41}$ As to the relative importance of such work to those clinics, patent and trademark work makes up a much larger percentage of the total work done across the community than copyright and trade secret. ${ }^{42}$

However, what may be more surprising is that a sizeable number of IP/T clinics also handle subject matter outside of the traditional IP realm. For example, just over half ${ }^{43}$ of IP/T clinics report that they draft policies related to privacy and data protection. Over a third of clinics $^{44}$ report that they are involved in regulatory and legislative topics, like the Digital Millennial Copyright Act (DMCA) or policy work involving the Federal Communications Commission, the Patent and Trademark Office, the Federal Trade Commission and the Federal Drug Administration. In the rather large "other work" category, over a third of the clinics ${ }^{45}$ go potentially even further afield, tackling cyber law issues as well as a wide variety of general corporate law needs, which can include corporate governance, financing, securities law, and even some aspects of employment law and immigration law. And $40 \%$ of clinics also report that they counsel on various state torts such as right of publicity, defamation, rights of privacy, interference with

kind of subject matter (in percentage points) the clinic doing the least amount of that kind of work does. In other words, looking at the chart, every IP/T clinic reporting does some amount of work involving Patent/Copyright/Trademark/Trade Secret, and the clinic that handles the least amount of that kind of work still does $15 \%$ as a percentage of their whole. The "Maximum" column shows the amount of work as a percentage of the whole that the clinic doing the most work with this subject matter does. The "Mean" column shows the average amount of work of a certain kind done across the IP/T clinical community, and the "Standard Deviation" shows how varied the distribution is. The "Count" column states how many clinics gave a value at all for handling a particular subject matter (as soon as a survey respondent touched the survey counter, the survey recorded at least a zero).

40 The count is 64 out of 69 clinics, or $93 \%$. Approximately $71 \%$ of IP/T clinics handle at least some patent work, $68 \%$ handle some copyright work, $84 \%$ handle some trademark work and $48 \%$ handle some trade secret work.

41 It may actually be surprising that there are some IP/T clinics that do not handle IP work at all. This exposes an interesting bifurcation in the community. Although technology law often overlaps with IP law, there are areas of technology law that constitute a distinct specialty, for example internet and computer fraud issues. The divide is noticeable as well when discussing clients and missions, but we consciously included technology clinics in our study because the IP and technology subject matter overlap is significant.

42 To represent how important the subject matter was to the various clinics, we asked clinics to approximate the volume of work as a percentage of the whole. The mean volume was: for trademarks $46 \%$, for patents $42 \%$, for copyrights $23 \%$ and for trade secret $11 \%$.

43 The count is 37 out of 69 clinics, or $53.6 \%$.

44 The count is 26 out of 69 clinics, or $37.7 \%$.

45 The count is 26 out of 69 clinics, $37.7 \%$ 
business, and other torts. ${ }^{46}$ Demonstrating the breadth of this practice, one clinic noted that the torts encountered are "too many to describe." 47

In summary, our community is possibly broader than might be expected. Similar to some traditional general practice clinics, the vast majority of IP/T clinics handle a wide variety of subject matter. This finding may reflect that the IP/T clinical community is composed of not only strictly IP clinics, but clinics that counsel in the much broader realm of "technology law." If this includes counseling technology clients, such clients' needs can expand beyond the traditional borders of IP.

2. Work Tasks: Most IP/T clinics handle a mix of issues. However, there are two notable exceptions: one sizeable sub-community of clinics focuses heavily or exclusively on rights acquisition; while another small group of clinics focuses heavily or exclusively on policy advocacy.

In the survey questions, we divided the universe of possible types of IP/T clinic work into five broad categories: prosecution/rights acquisition; non-prosecution transactional work; policy work; litigation; or other. We then asked the clinics whether they engaged in the work, and if so, to rank the work in terms of the resources they devoted to the work over time. We were not surprised to see that many IP/T clinics handled at least some prosecution/rights acquisition work and some transactional work, and that most clinics handled work from more than one category. However, the ranking of resources showed the surprising result that a sizeable percentage of IP clinics delved into one category of work alone.

First, the graph below illustrates the variety of work that IP/T clinics handle. It depicts the number of IP/T clinics that do at least some of a certain type of work.

46 The count is 28 out of 69 clinics, or $40.6 \%$.

47 New York University School of Law's Technology Law and Policy Clinic. 


\section{What Kind of Work Do You Handle as a Percentage OF THE WHOLE?}

\begin{tabular}{|c|c|c|c|c|c|}
\hline & Minimum & Maximum & Mean & $\begin{array}{c}\text { Standard } \\
\text { Deviation } \\
\end{array}$ & Count \\
\hline $\begin{array}{l}\text { Prosecution/rights } \\
\text { acquisition (e.g. USPTO } \\
\text { filings; TTAB and PTAB } \\
\text { work; prior art searches) }\end{array}$ & 0.00 & 100.00 & 55.28 & 33.00 & 60 \\
\hline $\begin{array}{l}\text { Non-prosecution } \\
\text { transactional/client } \\
\text { counseling (e.g. negotiation; } \\
\text { IP audits; drafting licenses, } \\
\text { policies, or contracts; fair } \\
\text { use analysis; freedom to } \\
\text { operate searches) }\end{array}$ & 3.00 & 100.00 & 40.23 & 23.51 & 52 \\
\hline $\begin{array}{l}\text { Policy work (e.g. white } \\
\text { papers; educational } \\
\text { outreach (best practices } \\
\text { guides, street law efforts); } \\
\text { lobbying; amicus briefs, } \\
\text { DMCA anti-circumvention; } \\
\text { FOIA requests) }\end{array}$ & 0.00 & 100.00 & 24.45 & 28.09 & 31 \\
\hline $\begin{array}{l}\text { Litigation (state and federal } \\
\text { courts, no TTAB or PTAB) }\end{array}$ & 0.00 & 90.00 & 11.57 & 18.76 & 21 \\
\hline Dther & 0.00 & 100.00 & 19.75 & 23.17 & 24 \\
\hline
\end{tabular}

The most common work, handled by over $85 \%$ of the IP/T clinical community ${ }^{48}$ is filing federal applications in order to secure IP rights, so called "prosecution/rights acquisition." 49 Of these clinics, most handle trademark prosecution, including running trademark searches, drafting clearance memos and opinion letters for clients, and filing and prosecuting federal applications. ${ }^{50}$ But some clinics do handle patent prosecution to some degree, including pre-filing prior art searches and opinion letters, and even filing provisional and nonprovisional patents. ${ }^{51}$

48 The count is 60 out of 69 respondents, or $87.0 \%$ of respondents.

49 In the IP realm, "prosecution" has a distinct definition-it is the process by which an applicant files for and then negotiates with the USPTO for a federal registration of a patent or trademark. "Prosecution" in the IP realm does not signify litigation.

5050 clinics file trademark applications versus 32 clinics that file provisional patent applications and 25 clinics that file nonprovisional applications for clients.

51 Id. 


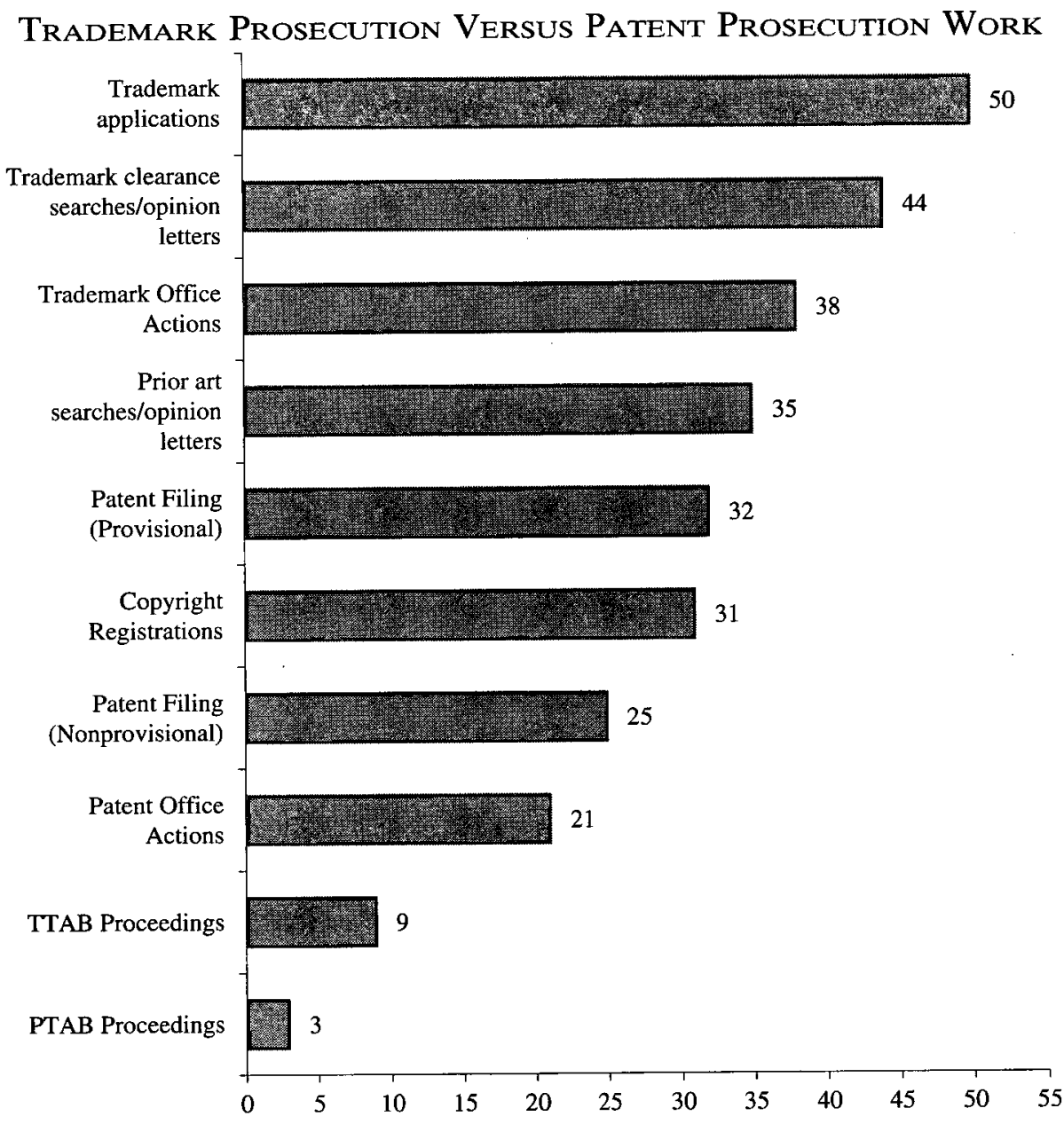

Besides the prosecution/rights acquisition work, over $75 \%$ of IP/T clinics engage more broadly in transactional counseling work. ${ }^{52}$ The variety of work this encompasses is depicted in the graph below, which shows the number of respondents that often perform a certain task:

52 The overall count is 52 out of 69 respondents, or $75.4 \%$. 


\section{Kinds of Non-Prosecution Transactional Work Handled Most Often}

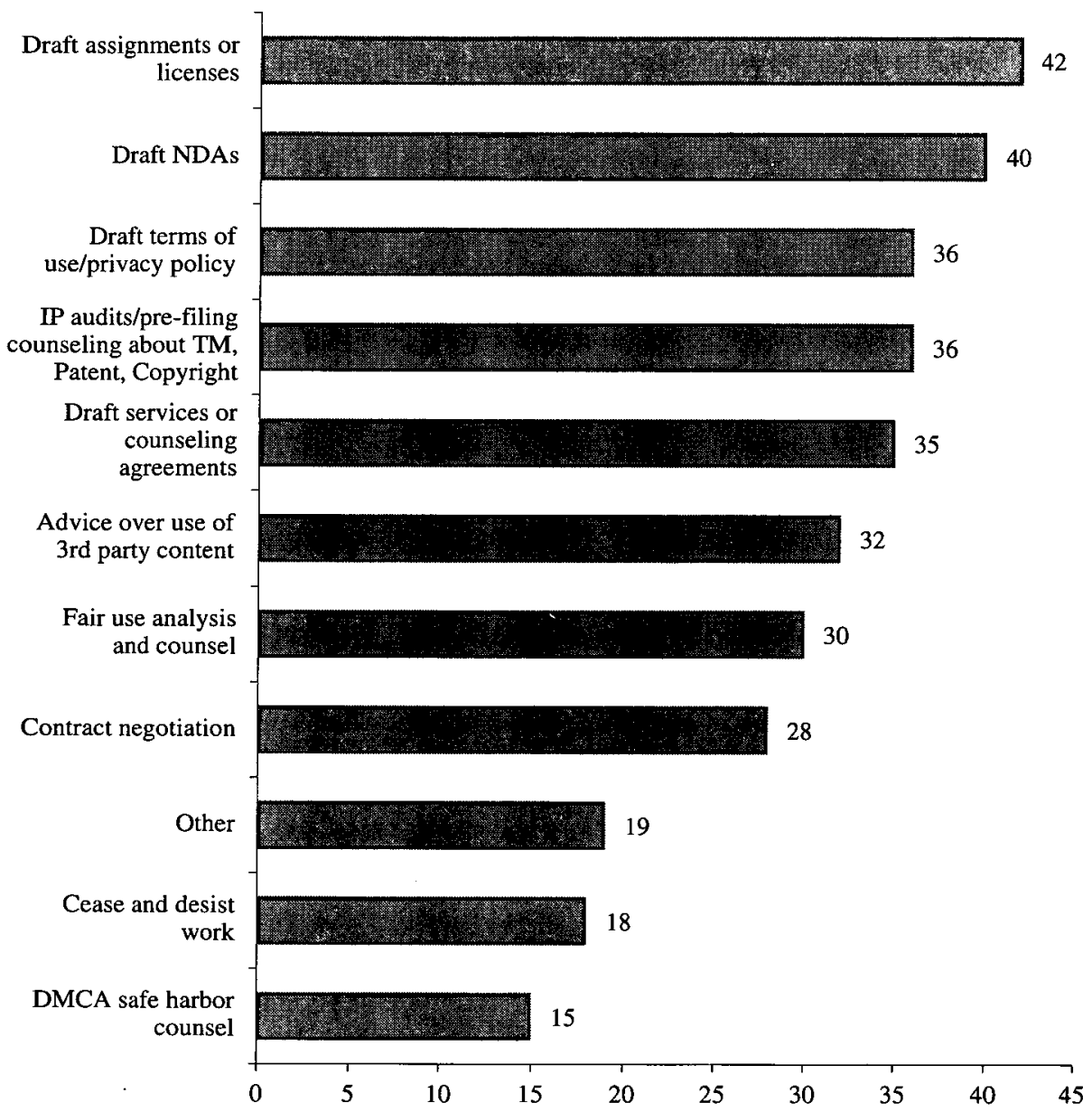

As shown, the transactional counseling work of the IP/T clinics is very broad. Such counseling might include, for example, how to use third party content within fair use parameters, ${ }^{53}$ how to post or host online content in compliance with the DMCA, ${ }^{54}$ and how to respond to a cease and desist letter. ${ }^{55}$ The work also includes drafting and negotiating a wide variety of contracts, including IP assignments or licenses, non-disclosure agreements, terms of use and privacy policies, and ser-

5330 clinics often do this work. The Benjamin N. Cardozo School of Law's Indie Film Clinic is an example.

54 California Western School of Law's New Media Rights Clinic in particular concentrates on defending their clients from DMCA takedown notices for their postings on online marketplaces such as Etsy and Amazon.

5518 clinics have counselled in this way-American University Washington College of Law's Glushko-Samuelson IP Clinic is one example. 
vice or consulting agreements. Many clinics are engaged in helping clients with entity selection and formation and drafting documents for corporate governance. 56 One final common area of work involves taking an IP audit, to help a client formulate an IP protection strategy. ${ }^{57}$

Besides rights acquisition and general transactional counseling, almost $45 \%$ of the IP/T clinic community 58 engages in policy advocacy. The breakdown is explained in the chart below.

56 Just some examples include: the Washington University in St. Louis School of Law's Entrepreneurship and IP Clinic; the University of Florida Levin College of Law Entrepreneurship Legal Practicum; the University of Richmond School of Law's IP and Transactional Law Clinic; the University of California Hastings College of the Law's Startup Legal Garage; and the University of San Diego School of Law's Entrepreneurship Clinic.

57 This is a particular specialty of the University of Washington School of Law's Entrepreneurship Clinic. Several clinics also specialize in certain "other" areas of counseling. The subject matter of the counseling often reflects clients endemic to their particular communities. For example, Benjamin N. Cardozo School of Law's Indie Film Clinic (located in New York City) has a sole focus on assisting independent ("indie") filmmakers with counsel over all stages of film production and distribution. Chapman University Fowler School of Law's Entertainment Law Clinic (located just outside Los Angeles) focuses on entertainment law activities for its clients including advertising/marketing, trademark, and website/social media use. Santa Clara University School of Law in Silicon Valley has a privacy certificate program, so its Entrepreneurs' Law Clinic does a good amount of privacy compliance work, evaluating policies and procedures around complying with COPPA, GDPR, etc., beyond just creating a consumer-facing privacy policy. Several other schools around the Silicon Valley, Boston and New York areas specialize in counseling around venture funding, or other aspects of startup formation. And given its proximity to the Canadian border, the University of Detroit Mercy School of Law's International IP Law Clinic specializes in international IP law, even operating a joint clinic with the University of Windsor (Ontario).

5831 out of 69 clinics, or $44.9 \%$. 


\section{What Kinds of Policy Work Do You Do?}

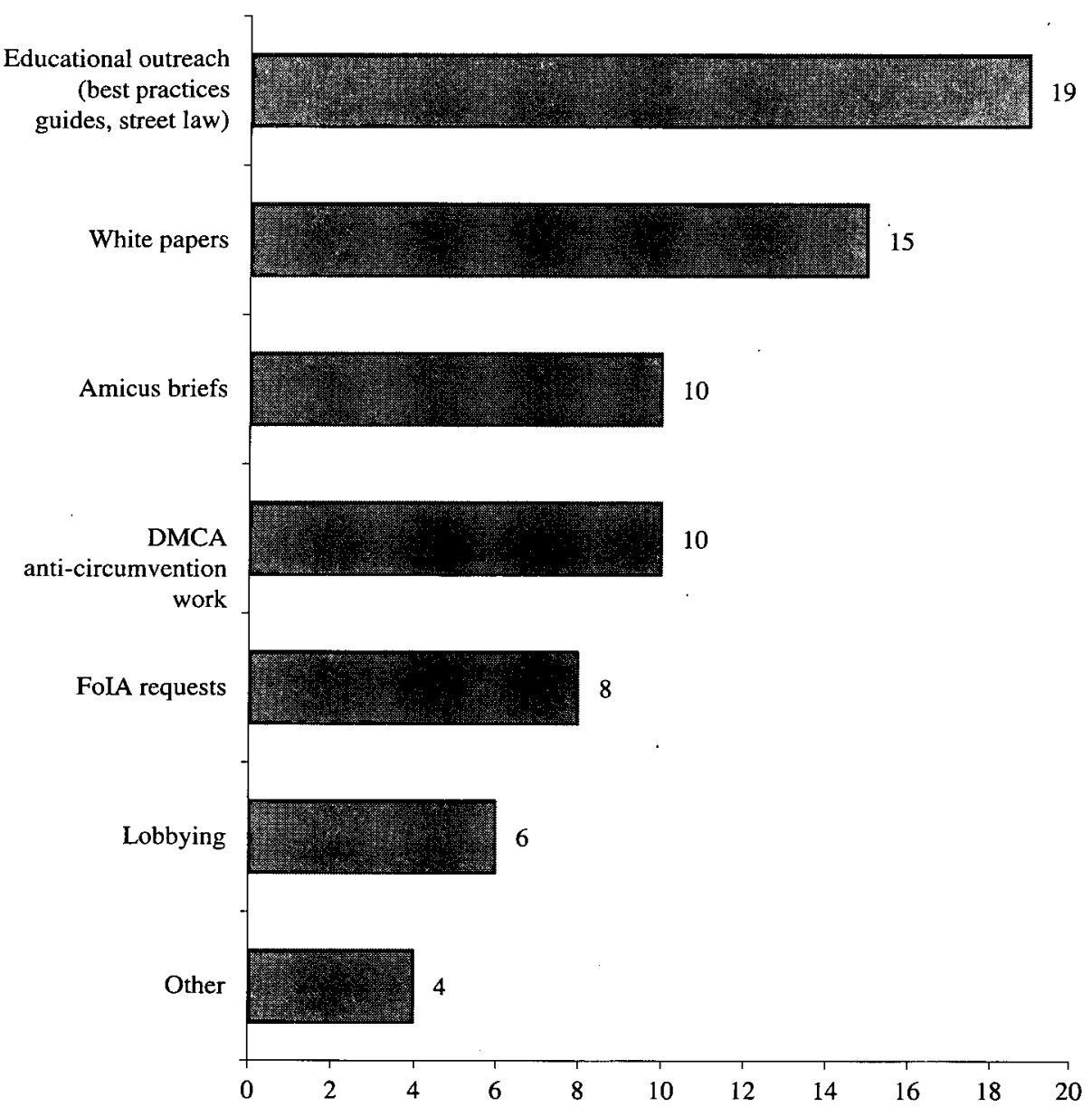

This work might take the form of writing-intensive educational outreach projects, such as drafting best practices guides, creating legal toolkits, or developing curricula for IP and technology educational programs. ${ }^{59}$ Clinics also draft white papers, ${ }^{60}$ prepare amicus briefs, ${ }^{61}$

59 Examples of such work include Harvard University School of Law's Cyberlaw Clinic, where students have educated teachers about fair use and middle school students about privacy law. University of California Berkeley School of Law's Samuelson Law, Technology, and Public Policy Clinic students have co-authored a guide to help authors determine whether open access is right for their works and, if so, how to make works openly accessible. American University, University of Southern California, and University of California at Irvine's clinics have all produced best practices guides for their creative and scholarly clients.

60 The University of Washington School of Law's Technology Law and Policy Clinic focuses on legislative initiatives and produced a white paper for legislators on Bitcoin and other crypto currencies. University of Colorado Boulder Law School's Glushko-Samuelson Technology Law and Policy Clinic has worked on numerous white papers in FCC- 
and submit comments or participate in rulemaking proceedings. ${ }^{62}$ Indeed, many of the consumers, scholars, and creators seeking (and being granted) needed exemptions under the anti-circumvention provisions of the DMCA have been represented by IP/T clinics. Clinics have also prepared FOIA requests, engaged in both federal and state lobbying, and done policy research to inform state and local legislative bodies. ${ }^{63}$ By doing such policy work, IP/T clinics have embraced a unique opportunity to play an active role in educating the community and in developing and commenting on relevant bodies of law. As discussed more in Section III (3), below, such policy advocacy fits well within the missions of many clinics in the IP and Technology community.

Rounding out the palate of work of the IP/T clinic community, a smaller but significant percentage of clinics ${ }^{64}$ represent clients in some litigation. ${ }^{65}$ Such work has included litigating FOIA requests, conducting free speech defense, fighting for rights of access, defending against condemnation, litigating copyright, trademark and trade secret claims, and one contract dispute case ${ }^{66}$ among other cases. Finally, a significant portion of clinics ${ }^{67}$ are engaged in "other" related work beyond these categories. This work covers a vast range of lawyering activities from general corporate legal assistance including helping

related matters.

61 Harvard's Cyberlaw Clinic has filed amicus briefs addressing a variety of topics including the implications of the fair use doctrine on the DMCA and immunity for platforms that host user-uploaded content. University of California Berkeley School of Law's Samuelson Law, Technology, and Public Policy Clinic filed an amicus brief to protect public access to archived TV news clips and political advertisements. American University Washington College of Law's Glushko-Samuelson IP Law Clinic filed two amicus briefs arguing that online content streaming services should receive $\$ 111$ compulsory licensing to increase not only consumer choice but also broad accessibility. New York University School of Law's Technology Law and Policy Clinic works heavily with the American Civil Liberties Union's Speech Privacy and Technology Project, through which it works on white papers, amicus briefs, and other policy work.

62 A common example of this is the triennial DMCA rulemaking process.

63 For example, Benjamin N. Cardozo School of Law's Tech Startup Clinic has established a working relationship with the New York Attorney General to explore the impact of technologies on government, and separately the regulatory impact around the "on demand" economy.

$6430 \%$ or 21 out of 69 clinics.

65 This does not include amicus brief activity, which we considered under policy work, or appearances before the Trademark Trial and Appeal Board and the Patent Trial and Appeal Board, which we classified under prosecution/rights acquisition.

66 In particular, the Yale University Law School's Media Freedom and Information Access Clinic has engaged in a large amount of litigation relating to technology, privacy, free speech, media law, national security, and surveillance issues. In one case, they challenged a National Security Letter gag order on First Amendment grounds. Harvard's Cyberlaw Clinic also litigated for the right to a cameras-in-the courtroom program all the way to the Massachusetts Supreme Court.

$6734.8 \%$, or 24 clinics. 
clients navigate their choice of entity, giving corporate governance advice, doing filings, and creating bylaws and operating agreements, ${ }^{68}$ to IP valuation and brand counseling, ${ }^{69} \mathrm{M} \& \mathrm{~A}$ consultation, ${ }^{70}$ mediating IP disputes, ${ }^{71}$ advice on open licensing, ${ }^{72}$ and even international IP filing strategy. ${ }^{73}$

In summary, by and large the IP/T clinical community handles a wide variety of subject matter over a wide variety of tasks. Although certain kinds of work are more prevalent than others, for the most part, even if clinics have a client specialization, they still offer a wide variety of lawyering services to their clients. However, there are two exceptions to that generalization. This information emerged when we asked not only about whether a clinic included a type of work in their offerings, but when we asked about the number of resources a clinic devoted to the work, or in other words how much of any kind of work the clinic performed.

The results were surprising. Not only does most of the IP/T community do at least some prosecution/rights acquisition work, but about a third ${ }^{74}$ focuses almost exclusively ( $75 \%$ or more of their clinical practice) on it. In other words, while $80 \%$ of the IP/T clinic community offers rights acquisition as one of many services offered, $30 \%$ offers primarily this service. We postulate that this phenomenon is likely related to the founding and rise of the USPTO student practice program. ${ }^{75}$ This statistic does reflect one possible anomaly of the IP/T clinic community, in that we have a sub-community of clinics that fo-

68 Many clinics are in this category, including University of Richmond School of Law's IP and Transactional Law Clinic; Washington University in St. Louis School of Law's Entrepreneurship and IP Clinic; University of California Hastings College of Law's Startup Legal Garage; and University of Florida Levin College of Law's Entrepreneurship Law Practicum.

69 University of Washington School of Law's Entrepreneurial Law Clinic.

70 University of San Diego School of Law's Entrepreneurship Clinic.

71 Suffolk University Law School's IP and Entrepreneurship Clinic.

72 Harvard University Law School's Cyberlaw Clinic.

73 University of Detroit Mercy School of Law's International IP Law Clinic.

$7431.9 \%$ or 22 clinics out of 69 .

75 Only 3 of the 20 clinics where prosecution/rights acquisition is $75 \%$ or more of their docket were founded before the USPTO program was started in 2008. In the year the program was started (2008) there were 3 new prosecution clinics, and the first time there was an expansion to the program (2013-2014), 6 new prosecution clinics came online. As a result, as of May, 2018, the Rutgers University Law School's IP Law Clinic reports that it has filed over 330 trademark applications-with well over two thirds of them referrals from the USPTO program-since its founding in 2013. Other trademark prosecution clinics such as those at California Western School of Law, North Carolina Central University School of Law, John Marshall Law School, Southern Methodist University Dedman School of Law, University of California Los Angeles, and Howard University Law School similarly work primarily with USPTO-referred clients, and California Western notes it was founded specifically to participate in the USPTO's clinic program. 
cuses on training students to do a very specific type of work. This type of clinic is also unique in that it is mostly taught by adjunct instead of full-time faculty.

The second anomaly is that while several clinics incorporate policy projects into their mix of client work, some of those clinics focus half or more of their attention on policy work. ${ }^{76}$. This means that a subcommunity of IP/T clinics is focused on fighting for the broader public interest through impact projects and litigation. ${ }^{77}$ These clinics are an integral part of the IP/T clinical community, yet they do not always follow the traditional clinical model of representing individual clients over a variety of legal needs. They also skew the survey results on clinic mission and typical client for IP/T clinics in interesting ways, as described more in Section III (3) below.

In summary, as with other clinical communities, the vast majority of IP/T clinics deliver a variety of legal work to their clients. However, perhaps different from some communities, of clinics, a significant percentage of the IP/T clinics are designed for one purpose: either to secure IP rights for clients or to advocate for policy issues. This may reflect the forces that led to those clinics' founding as well as the missions that continue to guide them.

\section{Overall Mission: The concept of clinic mission is nuanced for the} IP/T clinic community. All clinics have strong pedagogical missions, and many also have internally-or externally-imposed public interest missions. However, IP/T clinics may define "public interest" missions in a slightly different way than other parts of the clinical community, given that a large percentage of their client base consists of small for-profit entities. And certain clinics do pursue additional missions spawned by the difficult legal economy.

As with clinics overall, the IP/T clinics are mission-driven. Like

76 This is 7 out of the 31 clinics that do policy work, or $10 \%$ of the whole community, including Stanford University Law School's Juelsgaard IP and Innovation Clinic, University of California Berkeley School of Law's Samuelson Law, Technology, and Public Policy Clinic, University of Washington School of Law's Technology Law and Policy Clinic, University of Ottawa Faculty of Law's Samuelson Glushko Canadian Internet Policy and Public Interest Clinic, University of California Irvine School of Law's IP, Arts, and Technology Clinic, University of Colorado Boulder Law School's Samuelson Glushko Technology Law and Policy Clinic, and New York University School of Law's Technology Law and Policy Clinic.

77 One example includes the University of Washington School of Law's Technology Law and Policy Clinic, which has worked closely with the Uniform Law Commission on designing laws on the introduction of driverless cars and aiding the Chief Privacy Officer of Washington State on legislation creating a state office of privacy and data security. Clinic students have also helped to write laws on revenge porn. 
other clinics, IP/T clinics care deeply about pedagogy and effective teaching. But beyond that, IP/T clinics are also driven by internally or externally-imposed missions. These additional missions partially, but do not completely overlap with traditional clinical public interest missions to serve disadvantaged clients. The survey data uncovers interesting interplay between mission and client selection and helps to explain how this IP/T clinical community is inspired by, yet also transforms, the concept of clinics delivering access to justice.

\section{a. The IP/T clinics' missions are first and foremost pedagogical}

The survey statements show that the IP/T clinical community cares deeply about providing rich and successful learning opportunities for students. Although that means different things to different clinicians, the survey responses are rife with comments about introducing students to new concepts, helping them feel comfortable and accomplished as new practitioners, and challenging them to grow. ${ }^{78}$ Most IP/T clinics employ familiar aspects of the traditional clinical model to teach, for example, case rounds, a seminar to accompany the client work, written reflections, and consistent non-directive supervision. ${ }^{79}$ In philosophy and execution, the pedagogical goals of IP/T clinics are very much in line with the rest of the clinical community.

\section{b. IP/T clinics also operate under outward-facing public policy/ social justice missions}

Most of the IP/T clinics also have some outward-facing mission where the clinic plays a role in the community to further a cause beyond teaching the students. These missions often are multi-faceted, perhaps because they arise from a variety of sources. Some of these missions specifically guide the clinics to take on underrepresented clients, but other missions, equally strong and valid, guide clinics to ful-

78 At one school for example, they say they "try to bring on clients that will give our students a good range of work, and give the students opportunities to learn about professionalism and ethical questions that lawyers frequently encounter," and part of Boston College Law School's Entrepreneurship \& Innovation Clinic's mission is to "Empower students to become highly effective business law advisers by developing their arsenal of substantive knowledge and lawyering skills." Schools varied on whether they prized a goal of delivering a practical education to students or client-impact more. As two examples of schools that particularly emphasized gaining experience specifically directed to what students would experience in the workplace, the University of Arizona College of Law's IP Clinic indicated that the number one purpose of the clinical program was to "prepare students with practical experience." Likewise, the Chicago-Kent College of Law's IP Law Clinic catered its clinic to "create a law firm experience for students" and chose clients accordingly.

7948 out of 62 respondents to the question said they used case rounds, 28 of them either weekly or even more often. 65 out of 68 respondents to the question had a classroom component to the clinic. 
fill other missions that could also be considered in the "public interest."

Some such missions start with the clinic's founding. Several clinics mention their founders' or funders' desires and how that shaped their clinic design. ${ }^{80}$ In many cases, the founders and funders had a clear vision for a need they wanted the clinic to fill, which connected to an overall societal good. Although these clinics may not directly represent individual low-income clients, they are still operating with a public interest mission in mind. Some help the public interest through their policy projects, ${ }^{81}$ other clinics represent communities of student or local entrepreneurs, in the hope that successful companies will stimulate regional economic growth, ${ }^{82}$ and some represent the university technology transfer office, in the hope that they can help early stage medical technologies to become products to affect public health. ${ }^{83}$

Other times the outward-facing mission is a reflection of the clinical faculty members' interests or specialties. They will seek out clients that will allow them to advocate for issues or clients that have a social mission that is personally important to them. Other clinicians have used their clinics as a platform to attack injustice, for example to empower parties falling victim to trademark bullying. ${ }^{84}$ And several

${ }^{80}$ For example, the Samuelson-Glushko clinics (University of Ottawa, American University, University of Colorado Boulder, Fordham University, and University of California Berkeley) were founded in part to help students explore policy questions and make positive change critical to IP and technology innovation. Both the University of Maryland Francis King Carey School of Law's IP and Entrepreneurship Clinic and the University of Connecticut School of Law's IP and Entrepreneurship Law Clinic were funded by government money to impact the state (Connecticut) or local (Maryland) economy. The University of Pennsylvania Law School's Detkin IP and Technology Legal Clinic was founded in part to work with the university technology transfer office. Several clinics were founded specifically to work with student entrepreneurs: the Boston University School of Law-Massachusetts Institute of Technology's Entrepreneurship, IP and Cyberlaw Program (with two clinics) was established for students from both universities; the University of Illinois at Urbana-Champaign College of Law's IP Clinic was founded to take work exclusively from the engineering school at the university; and the Northeastern University School of Law's IP Co-lab was founded specifically to serve both graduate and undergraduate students to support their entrepreneurial ventures. And several clinics acknowledge that they came online to be part of the USPTO Law School Clinic Certification Program.

81 See the Samuelson-Glushko clinics.

82 See the University of Maryland Francis King Carey School of Law's IP and Entrepreneurship Clinic and the University of Connecticut School of Law's IP and Entrepreneurship Law Clinic.

83 See the University of Pennsylvania Law School's Detkin IP and Technology Legal Clinic.

84 "Trademark bullies" refers to parties, often large companies, that vigorously oppose trademark applications for non-similar marks usually filed by smaller unrepresented individuals and companies, expecting the applicant to abandon the application rather than incur huge legal fees to fight the opposition. Clinics at Fordham University, American University, Suffolk University, and University of Colorado Boulder have all taken on cli- 
clinics located in specific locales have leveraged their work to attempt to improve the local economy and create jobs. ${ }^{85}$ In fact, several of these clinics state that they do not select clients, but rather take clients in order of application, since the need for affordable counsel is so great and their clinic waiting lists are so long. Although not every client is selected on the basis of financial need, these clinics are working overall toward the public interest mission of shoring up local start-ups in the hope of jumpstarting community economies. ${ }^{86}$

\section{c. Some IP/T clinics also embrace missions inspired by the needs of the economic reality during which they were founded}

Several IP/T clinics were quite overt about reporting missions to help students find employment after graduation. ${ }^{87}$ Although this does not naturally fit into the discussion about larger social or public policy missions, in the current legal market, IP/T clinics are likely not alone in trying to fulfill a practical vocational goal for students. Pursuing such missions also tends to encourage clinics to bring larger and wealthier clients onto the client roster to introduce students to sophisticated technologies and cutting edge legal issues so they might develop an expertise, as well as good connections. As with the clinics that do primarily prosecution/rights acquisition work, when clinics embrace vocational success as a clinic mission, students get a head start on niche work they might continue to practice in their career. IP/T clinics might be uniquely situated to pursue such a mission, in that their clients tend to be business focused, which matches up with the first career steps of many of our students. The survey results did not reveal whether or not pursuing such a vocational mission is unique to IP/T clinics, but this may be one situation where the IP/T clinic community diverges from the rest of the clinical community.

\section{Clients: IP/T clinics create a client portfolio that fulfills and drives their missions. For most clinics, this means a combination}

ents that allow the students to address trademark bullying.

85 See John Marshall Law School in Chicago, Illinois, St. Louis University School of Law in St. Louis, Missouri, Wayne State University Law School in Detroit, Michigan, and the University of Puerto Rico School of Law.

86 Providing legal services to small-business owners unable to afford counsel is a crucial tool of economic empowerment. For a discussion of economic justice and transactional law, see Pantin, supra note 28, at 199 ("Entrepreneurship is a vital component to achieving economic justice and realizing the dream articulated in Dr. King's speech. . Economic empowerment, income, and asset accumulation are large parts of the equation for economic justice. Transactional lawyers and transactional clinics naturally play a role in furthering economic justice through entrepreneurship.").

87 One example, among others, is Benjamin N. Cardozo School of Law. 
of for-profit and non-profit small entities and individuals, but some clinics pursue their missions by working with at least some large non-profits, large for-profits, or university technology transfer offices.

The survey data confirms that the pedagogical, public interest, and vocational missions of the IP/T clinic community drives its client base. Each clinic chooses clients that emphasize and help it to achieve its unique combination of missions, and in turn, clients can refine or shift missions. Our survey inquired whether and to what extent IP/T clinics accept i) small start-ups; ii) medium and large for-profits; iii) small non-profits; iv) medium and large non-profits; v) individuals; and vi) other clients. The results were as follows:

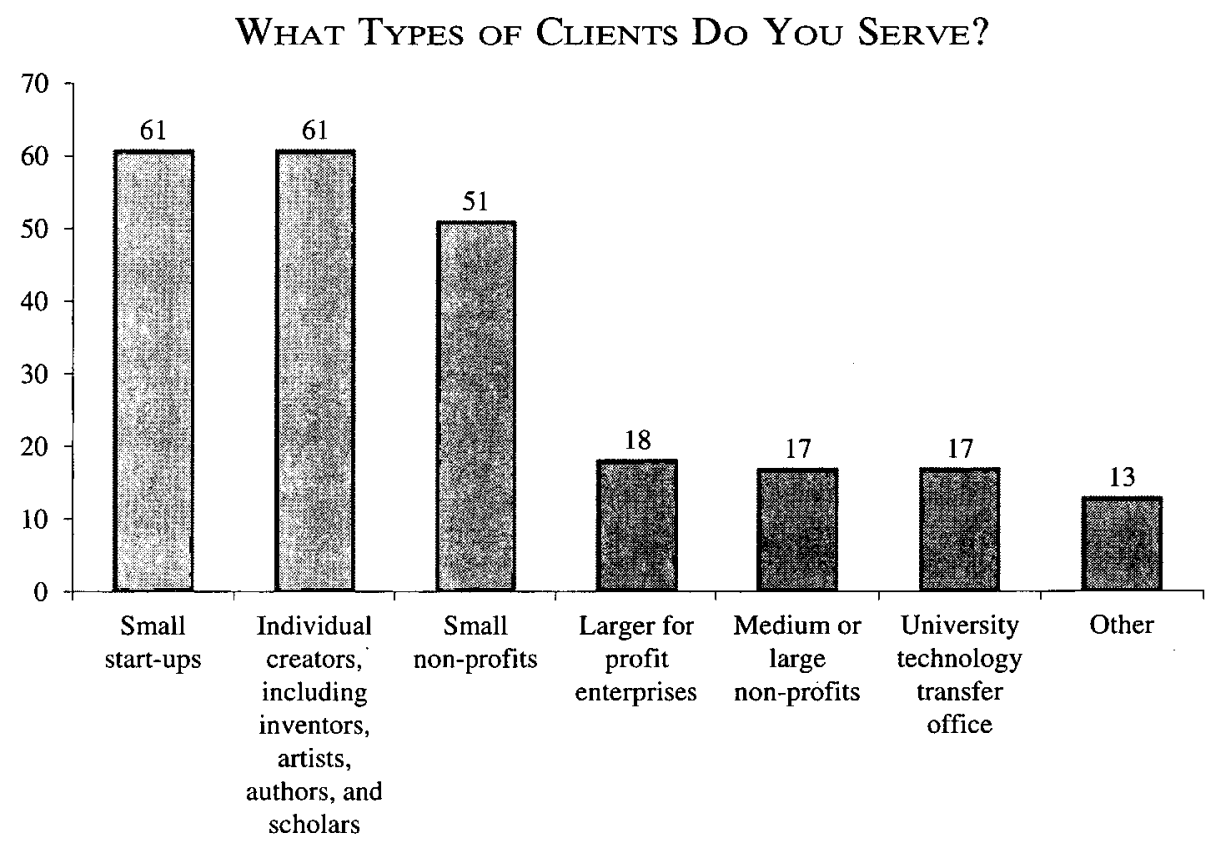

Similar to other clinical communities, IP/T clinics represent many individuals. However, IP/T clinics also represent many small entities, both for-profit and non-profit. ${ }^{88}$ This diverse client makeup may be a departure from some other types of clinics in the larger clinical community ${ }^{89}$ The skew towards individuals and small entities is partly explained by the fact that the clinics that focus primarily on prosecution

8861 out of 69 responding clinics or $88.4 \%$ handle small for profit start-ups, and 51 out of 69 clinics or $73.9 \%$ handle small non-profits.

89 However, the client makeup of IP/T clinics may be most similar to that of entrepreneurship clinics or community economic development clinics. 
and rights acquisition ${ }^{90}$ serve nearly exclusively small start-ups and individuals $^{91}$ while not handling large clients at all, whether non-profit or for-profit. ${ }^{92}$ However, as a whole, the IP/T clinic community does accept a large percentage of clients that are entities.

In order to quantify the importance of these clients to IP/T clinics, we asked not only what kinds of clients the clinics handle, but also what percentage of their client load consists of each kind of client. We also asked clinics to further explain their clients within each category. Although all the data we received goes beyond the scope of this paper, some trends and specializations emerge that provide further information about mission, and also draw distinctions between the IP/T clinic community and others, and the clinics in the community from each other. The results are set forth in the following chart, and discussed more in the sections below.

Types of Clients as a Percentage of the Whole

\begin{tabular}{|c|c|c|c|c|c|}
\hline & Minimum & Maximum & Mean & $\begin{array}{l}\text { Standard } \\
\text { Deviation }\end{array}$ & Count \\
\hline Small start-ups & 0.00 & 100.00 & 47.05 & 27.46 & 61 \\
\hline Larger for profit enterprises & 0.00 & 30.00 & 4.50 & 7.90 & 18 \\
\hline Small non-profits & 0.00 & 50.00 & 17.14 & 12.95 & 51 \\
\hline Medium or large non-profits & 1.00 & 50.00 & 18.18 & 14.20 & 17 \\
\hline $\begin{array}{l}\text { University technology } \\
\text { transfer office }\end{array}$ & 0.00 & 70.00 & 12.94 & 17.87 & 17 \\
\hline $\begin{array}{l}\text { Individual creators, } \\
\text { including inventors, artists, } \\
\text { authors and scholars }\end{array}$ & 0.00 & 100.00 & 37.92 & 26.01 & 61 \\
\hline Other & 0.00 & 100.00 & 18.15 & 24.72 & 13 \\
\hline
\end{tabular}

a. For-Profit startups are the most important client for the IP/T clinic community.

Not only do IP/T clinics work with for-profit start-ups as much or more than any other kind of client category, ${ }^{93}$ but the IP/T clinics tend to take on more work for start-ups on average as a percentage of the whole than any other kind of client. ${ }^{94}$ In fact, there are several clinics

\footnotetext{
90 Approximately $30 \%$ of the IP/T clinics community.

91 Out of 20 such clinics, 19 handle small start-ups, 14 handle small non-profits, and 19 handle individuals.

92 Only 1 handles large for profits and 2 of the 20 clinics do work for university technology transfer offices, which is technically a large non-profit. None of the clinics work for other large non-profits.

93 Tied with individual creators, at 61 out of 69 clinics.

94 The community mean for start-up work as a percentage of the whole is $47.1 \%$.
} 
whose client mix is entirely for-profit start-ups, ${ }^{95}$ although the standard deviation is high. One popular specialization is the student entrepreneurial venture. ${ }^{96}$ Other clinics favor start-ups in a specific industry. ${ }^{97}$ Still other clinics choose startup clients from geographic areas or population groups that the clinic wants to serve. ${ }^{98}$ Finally, other clinics relay that they have developed a specialty based on working with a type of start-up client they see again and again, which can stem from factors like community need or the local economy. ${ }^{99}$

The choice to work with for-profit start-ups, or to work with specific kinds of for-profit startups, seems predictable as startup clients reflect the IP/T clinic community's preferred subject matter, preferred tasks, and missions. Startup clients often need prosecution/rights acquisition and general transactional counseling. Working with certain startups, for example student entrepreneurs, or minority owned businesses from a depressed district, reflects many clinics' originating purposes, if not also a public interest mission to strengthen the community by building company value. And by choosing clients that deal with certain technologies, a clinic can meet the pedagogical mission to introduce subject matter that students may find helpful in their

95 For example, the University of California Hastings College of Law's Startup Legal Garage student-attorneys collaborate with law firms and work with San Francisco Bay Area startup community.

96 The Boston University School of Law-Massachusetts Institute of Technology's Entrepreneurship and IP Clinic, Northeastern University Law School's IP Co-Lab, and University of Illinois at Urbana-Champaign College of Law's IP Clinic were all founded to assist student entrepreneurial ventures. At Case Western Reserve School of Law's IP Venture Clinic, students and recent graduates make up the $70 \%$ of clinic clients that are small start-ups.

97 For example, Benjamin N. Cardozo School of Law's Tech Startup Clinic focuses on New York-based start-ups based on cutting edge technology, especially in the realms of block chain, the internet of things, e-commerce, and fashion. Similarly, University of California Hastings School of Law's Startup Garage Law Clinic has two tracks of start-up clients: general technology or biotechnology.

98 For example, John Marshall Law School focuses on minority owned start-ups in the Chicago metropolitan area with the goal of job creation and increasing wealth in that city. DePaul University College of Law's Technology/Intellectual Property Clinic, another Chicago school, gathers its clients with the goal of "protecting the work of creative minds." The University of Akron School of Law's Trademark Clinic focuses on Ohio start-ups in operation less than 5 years with annual revenue of less than $\$ 100,000$. Meanwhile, the University of California Hastings School of Law's Startup Garage Law Clinic seeks out companies that are founded by women and minority entrepreneurs. And University of California Irvine School of Law's IP, Arts, and Technology Clinic seeks out "counseling to clients in the developing world."

99 For example, both Harvard University Law School's Cyberlaw Clinic (in Boston, Massachusetts) and Howard University School of Law's IP and Trademark Clinic (in Washington, D.C.) have helped many education-based start-up companies. Further, California Western School of Law's New Media Rights Clinic (in San Diego, California) administers to many companies based around web-based services and applications, and several other clinics describe a steady diet of technology-focused clients. 
careers. The client choice often furthers the mission, but it can also refine a mission over time, as clinics develop a specialization based on their community need. Clinic mission and client choice are intertwined and codependent, and the IP/T clinic community's reliance on the startup client makes sense given what the survey data reveals about missions.

\section{b. The IP/T clinic community also relies heavily on individual clients, mostly inventors and arts creatives.}

The IP/T clinics also service a large number of individual creator clients, like business people/inventors, artists, musicians, filmmakers, content or software creators, academics, and authors. However, individuals make up slightly less of these clinics' client load on average than for-profit start-ups. ${ }^{100}$ There are very few true specializations. Of the clinics that do specialize in a certain type of individual client, that specialization focuses around an aspect of the arts or a type of inventor. ${ }^{101}$ As with for-profit startups, this focus on individual clients fits in well with the missions of IP/T clinics, in that individuals need prosecution and rights acquisition, as well as general transactional counseling help. The subject matter of the counseling may differ from that offered to for-profit startups, but is still in the realm of the subject matter favored by IP/T clinics.

c. Many clinics do represent some small non-profit clients, but that does not make up a large percentage of the whole.

The results on small non-profits were interesting. While a sizeable number of IP/T clinics do some work for small non-profit entities, ${ }^{102}$ these entities nonetheless make up a much smaller percentage of the whole on average than for-profit startup and individual clients. ${ }^{103}$ Even the clinic that accepts the most small non-profit clients tops out at $50 \%$ of its total client docket. ${ }^{104}$ The clinics' choice of small non-profit entities often mimics their choice of for-profit startups, often coming back again to mission. Some choose small non-

100 The mean percentage is $37.9 \%$, versus $47.1 \%$ for for-profit start-ups.

101 For example, Benjamin N. Cardozo School of Law's Indie Film Clinic focuses on independent filmmakers. Ave Maria School of Law's Patent Law Clinic focuses $100 \%$ on doing patent prosecution for first-time inventors.

102 The percentage of clinics that represent small non-profit clients is $73.9 \%$, or 51 out of 69 clinics.

103 Small non-profit clients make up only a mean percentage of $17.1 \%$ of all client work, versus $37.9 \%$ individuals and $47.1 \%$ for-profit start-ups.

104 University of Colorado Boulder Law School's Samuelson-Glushko Technology Law and Policy Clinic. 
profits to complement the clinic's subject matter expertise, ${ }^{105}$ some choose those that have a public interest mission that furthers the clinic's public interest mission, ${ }^{106}$ some choose certain small non-profits for their ability to serve a certain population or geographic area, ${ }^{107}$ and some continue to choose small non-profits in a similar space, perhaps because they have built up an expertise, or perhaps as a good reputation leads similar clients to apply. ${ }^{108}$

\section{d. Many fewer clinics represent larger clients, and when they do, the representation is tied very closely to that particular clinic's mission.}

Only a minority of clinics represent larger interests: only 17 clinics represent medium/large non-profits; 17 clinics do client work for a university technology transfer office, and 18 clinics represent larger for-profit ventures. The disparity between the numbers of clinics that work with smaller clients and those that work with larger clients is notable, and undoubtedly relates to mission.

The large non-profit clients in the survey are generally appropriate for the policy work of those clinics that take on such work. Since there are fewer clinics that focus a significant part of their docket on this work, it is not surprising that medium to large non-profits make up a small percentage of the total number of clients across the IP/T

105 Two clinics (Benjamin N. Cardozo School of Law's Tech Startup Clinic and University of California Hastings School of Law's Startup Legal Garage) will only take on nonprofits in the technology space; California Western School of Law's New Media Rights Clinic, which specializes in copyright law, handles many journalism and creative non-profits; Benjamin N. Cardozo School of Law's Indie Film Clinic focuses on non-profit film festivals and filmmaking entities; Thomas Jefferson School of Law's Art and Entertainment Law Clinic focuses on nonprofits that support visual and performing artists, filmmakers, and writers.

106 University of California Los Angeles School of Law's Patent Law Clinic seeks out "charitable entities involved in religious mission projects;" Stanford clusters around nonprofits that specialize in IP/innovation grassroots policy; the New Media Rights Clinic at California Western School of Law has helped many journalism nonprofits "helping shine a light on issues that don't get covered widely" as well as creative nonprofits; Yale has helped small advocacy organizations and non-profit news outlets.

107 John Marshall Law School's IP Clinic describes experiences with "art and veteran service organizations." Other clinics like Howard University School of Law's IP and Trademark Clinic, and Rutgers University Law School's IP Clinic mention a geographic cluster. Still others like St. Louis University Law School's Entrepreneurship and Community Development Clinic or University of Ottawa Faculty of Law's Samuelson-Glushko Canadian Internet Policy and Public Interest Clinic focus on non-profit organization clients that are community development or civil society entities.

108 The York University Osgoode Hall Law School's IP Osgoode Innovation Clinic has lately sought out nonprofits focused on indigenous and traditional knowledge issues. Howard University School of Law's IP and Trademark Clinic and Fordham University School of Law's Samuelson-Glushko IP and Information Law Clinic have handled many educational and social work non-profits. 
clinic community. However, the fact that medium to large non-profits rank at all as a client type is because some of the clinics that do represent them make them an important part of their client portfolio. ${ }^{109}$ Besides the clinics that take on primarily policy and advocacy work, general transactional clinics that also take on policy and litigation projects have also represented large non-profits when it furthered either their subject matter, public policy or pedagogical missions. ${ }^{110}$

Only 17 IP/T clinics handle work from their university technology transfer office. ${ }^{111}$ Most clinic university technology transfer work clusters around patent prosecution on the one hand, and business-informed legal advice for university spin-off companies on the other. ${ }^{112}$ Clinics need to tread carefully so as to avoid conflicts when doing this work, which may be the reason why it is not more popular. ${ }^{113}$ Clinics are more inclined to work with university employees after the technology transfer office has waived ownership of the technology rather than naming the technology transfer office itself as a client, ${ }^{114}$ or to represent the technology transfer office as a client over limited work, such as educational programming. ${ }^{115}$ Still, certain clinics are attracted to this work for the sophisticated technologies potentially involved,

109 University of California Berkeley School of Law's Samuelson Law, Technology, and Public Policy Clinic, for example, reports that medium or larger non-profits make up $45 \%$ of its client docket; University of Colorado Boulder Law School's Samuelson-Glushko Technology, Law, and Policy Clinic reports such clients make up 50\% of its client docket.

110 University of Ottawa Faculty of Law's Samuelson-Glushko Canadian Internet Policy and Public Interest Clinic generally partners with larger non-profit clients on litigation. American University Washington College of Law's Glushko-Samuelson IP Clinic focuses on amicus work for a variety of missioned clients. Fordham University School of Law's Samuelson-Glushko IP and Information Law Clinic clusters on non-profits involved in community organizing. Harvard University School of Law's Cyberlaw Clinic focuses on the public media space and major technology policy and advocacy non-profits. Similar to its work with smaller non-profits, Stanford has represented large non-profit education-related organizations.

111 A technology transfer office is the arm of the university that is in charge of commercializing early stage technologies created in the university classrooms and laboratories.

112 University of Notre Dame Law School's IP and Entrepreneurship Clinic, the University of Dayton School of Law IP Law Clinic, and the University of Detroit Mercy School of Law's International IP Clinic focus on prosecution, and the University of Washington School of Law's Entrepreneurial Law Clinic and University of Pennsylvania Law School's Detkin IP and Technology Legal Clinic focus on the legal advice. George Mason University Antonin Scalia School of Law's Arts and Entertainment Advocacy Clinic previously conducted a sizeable amount of prosecution work for its university technology transfer office in the past ( $70 \%$ of its total client docket).

113 For a discussion of potential solutions to ethical challenges when clinics do client work for the university technological transfer office, see Cynthia Dahl, Solving Ethical Puzzles to Unlock University Technology Transfer Office Client Work for an Intellectual Property Legal Clinic, 23 B.U. J. SCI. \& TECH. L. 1 (2017).

114 As at University of Washington School of Law's Entrepreneurship and Intellectual Property IP Clinic.

115 As at University of New Hampshire School of Law's IP and Transaction Clinic. 
and also to further a potential public policy mission of helping valuable early stage technologies, particularly in the life sciences, make it to the market. ${ }^{116}$

Finally, only 18 clinics ever represent large for-profit companies. Perhaps this is partially because even clinics that consider it a public interest mission to strengthen the community through strengthening local companies tend to focus their work on small for-profit companies. However, the few clinics that do work for larger for-profit companies ascribe to either a specific pedagogical or vocational mission. Furthermore, even when clinics do take on large for-profit clients, that work comprises a very small percentage of their client portfolio. ${ }^{117}$

Clinics were somewhat cautious as they explained their work for larger for-profit institutions. There might be a perceived conflict between doing work for large for-profit clients and traditional clinical missions to primarily help underserved or low income clients. On the other hand, the IP/T clinical community is not particularly constrained by strict income restrictions, as discussed in more detail in Section III (5) below. At the same time, taking on large for-profit clients can definitely further certain clinical goals, like exposing students to varied and unusual issues of law, giving them the opportunity to have clients that may be more like the clients they will experience in private practice, and giving them the chance to interact with other legal professionals. ${ }^{118}$

116 As at University of Pennsylvania Law School's Detkin IP and Technology Legal Clinic.

117 The mean percentage of the whole for clinics that take on large for-profit clients is $4.5 \%$.

118 For example, Benjamin N. Cardozo School of Law's Tech Startup Clinic students work alongside in-house counsel at larger funded startups to expose the students to more sophisticated problems as they do work that would not otherwise go to outside counsel. University of Pennsylvania School of Law's Detkin IP and Technology Legal Clinic has had students do some trademark work for a major pharmaceutical company in order to expose students to some topics they couldn't experience with a smaller startup client, like sophisticated anti-counterfeiting policies, international filing strategies, and the additional layer the FDA imposes on trademarks for drugs. Arizona State University Sandra Day O'Connor School of Law's Lisa Foundation Patent Law Clinic has done patent work for a large private neuro innovation center. The University of Missouri School of Law's Entrepreneurship Legal Clinic accepts a higher percentage of larger for-profit enterprises than other clinics, at $30 \%$ of a total client percentage. However, the clinic only handles forprofit enterprises, so this number is only a portion of their total for-profit docket, most of which consists of small start-ups. 
5. Client Selection Metrics. Typical metrics used to choose clients are not universally followed by the IP/T clinic community.

Income caps are somewhat important, especially to prosecution clinics, and metrics measuring missions to promote policy change were important to policy and advocacy clinics.

In order to understand what drives the IP/T clinics to choose certain clients, and to compare the results for this community to the clinical community at large, the survey asked clinics to rank a series of factors contributing to client selection on a five-point scale ranging from "Not at all important" to "Mandatory". We asked whether it was important to clinics that prospective clients exhibit the following factors: i) "have a greater social mission;" ii) "are under a set income cap;" iii) "represent a larger class;" iv) present a unique question of law," and v) "bring a larger policy issue to the forefront." The results were as follows:

How Important Is It That Clients That You Choose:

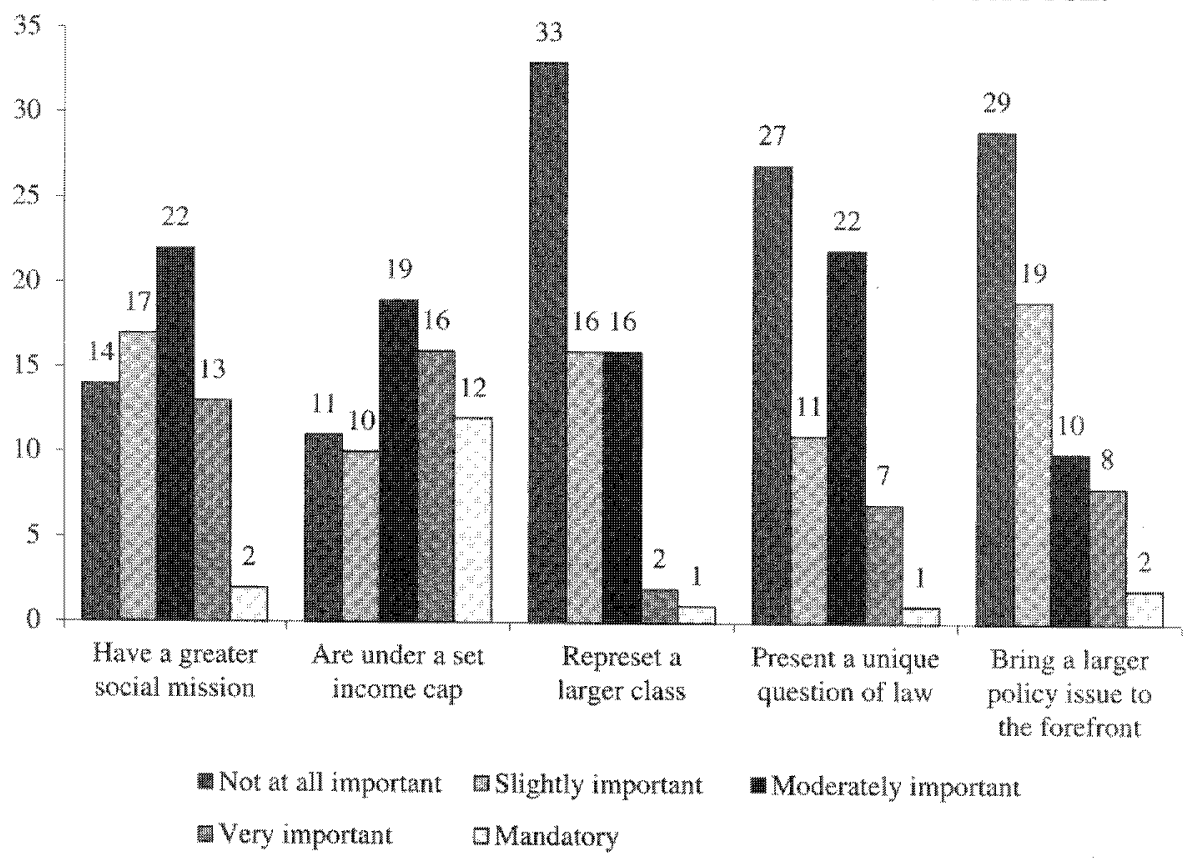

a. We did not identify a universal driving factor for client selection across the IP/T clinics community

Two of the factors we presented were designed to appeal to clinics' public policy missions to promote changes in the community or world ("represent a larger class" and "bring a larger policy issue to the forefront"); one was designed to appeal to clinics' academic or peda- 
gogical missions to impact or teach about new areas in IP law ("present a unique question of law"); and two were designed to appeal to social justice missions ("are under a set income cap" and "have a greater social mission"). In this way, we hoped to identify whether and to what extent public policy, academic or social justice missions were important to the IP/T clinical community, and whether those missions were important enough to drive client selection.

Overall, no one of these factors was critical or even important to the entire IP/T clinical community, although certain of the factors guided client selection more significantly than others, and certain of the factors played a more important role to certain kinds of clinics than to others. The majority of the clinics, for example, did have at least a slight preference for choosing clients that had a social mission, ${ }^{119}$ although for the majority this factor didn't rise to the level of being "very important," and a significant percentage ${ }^{120}$ said that client social mission was "not at all" important in the client selection analysis. So for the majority of clinics, furthering their own missions by choosing clients with social missions is only "slightly" or "moderately" compelling. Other factors more strongly drive client selection.

More of the clinics are concerned about clients being subject to an income cap, ${ }^{121}$ but it is still far from a universal concern. In fact, while this factor received more "mandatory" rankings than any other factor, the clinic responses still form a bell curve. Slightly over $40 \%$ of clinics responding claim income is either "mandatory," or "very important;" 122 about $25 \%$ claim income is "moderately important;" 123 and a little less than a third claim income is either "slightly important" or "not at all important." 124

On the other hand, between 40 and $50 \%$ of all clinics surveyed thought it was "not at all important" if clients represented a larger class, ${ }^{125}$ presented a unique question of law, 126 or brought a larger policy issue to the forefront. ${ }^{127}$ If income cap and social mission were only moderately important, these additional indicators of public policy or academic mission were even less relevant to client selection.

119 The mean importance of this factor was 2.59 out of 5.0.

$12020.6 \%$ or 14 out of 68 . Only 68 of the 69 survey respondents answered this set of questions.

121 This factor had a mean of 3.12 out of 5.0.

122 The percentage of responding clinics was $41.2 \%$, or 28 out of 68 .

123 The percentage of responding clinics was $27.9 \%$ or 19 out of 68 .

124 The percentage of responding clinics was $30.9 \%$, or 21 out of 68

125 The percentage of responding clinics was $48.5 \%$ or 33 out of 68 .

126 The percentage of responding clinics was $39.7 \%$ or 27 out of 68 .

127 The percentage of responding clinics was $42.6 \%$ or 29 out of 68 . 


\section{b. There is some consistency across clinic type in terms of factors driving client selection}

Did certain missions play a larger role in client selection for certain kinds of clinics? The survey data revealed some patterns. Interestingly, we found an inverse relationship between a preference that clients qualify under an income cap and a preference that clients support an academic mission or have a public policy mission.

Clinics that conduct at least $75 \%$ rights acquisition work most favor income caps in their client selection. Of the twelve clinics that declared that an income cap for the client was mandatory, nine were clinics that did a majority prosecution rights acquisition work. On the other hand, the clinics that did primarily policy and advocacy work care more about choosing clients that themselves have a social mission, bring a larger policy issue to the forefront, present a unique question of law, and represent a larger class. In fact, only two clinics, both clinics that handle $100 \%$ policy and advocacy work, account for all the "mandatory" ratings for these four factors. ${ }^{128}$ Conversely, these policy clinics do not prioritize income caps as a factor for client selection. ${ }^{129}$

In other words, the clinics that administer primarily to low income clients are not the same clinics that prefer clients that represent a larger class, present a unique question of law or bring a larger policy issue to the forefront. Clinics handling impact litigation or advocating for policy change are not administering necessarily to low-income clients, even though they would likely categorize their work as being in the public interest.

\section{c. Clinics Do Use Income Caps, but Not Consistently or Objectively}

Because income caps were somewhat important to at least a percentage of the community, the survey asked clinics that did have an income cap to describe their cap with more detail. By and large, IP/T clinics do not universally apply income caps, and the caps they use are vague in many cases. ${ }^{130}$ Of the clinics that claimed they imposed an

128 New York University School of Law's Technology Law and Policy Clinic and University of Colorado Boulder Law School's Samuelson-Glushko Technology Law and Policy Clinic.

129 For New York University, income is a "slightly important" factor, and for University of Colorado Boulder it is "moderately important," while the rest of the factors are either "mandatory" or "very important."

130 Only 32 of our surveyed clinics describe an income/budget/funding test for their clients at all, and only 14 clinics out of that 32 give a set amount for the cap. Clinics that indicated strong support for an income cap include University of Akron School of Law, Thomas Jefferson School of Law, Texas A\&M University School of Law, the University of 
income cap, about half of those clinics said that they determined the client was "in need" by asking clients to answer questions in good faith about their ability to otherwise afford services for the work in question within the market in question. ${ }^{131}$ However, because the cap for the clinics in this group was tied to the client's answers and not tied to either a specific set of conditions or a specific set amount, there was the potential for unequal treatment or inaccurate results.

A smaller group of clinics did impose a per se income cap. Some based the cap on an external metric. ${ }^{132}$ Other clinics relied on specific monetary amounts. ${ }^{133}$ However, setting a strict cap tied to a specific amount also presented problems. For one thing, it was not often clear which assets the clinics with per se income caps took into account when calculating income, for example, if a student entrepreneurial venture needed to disclose assets of the parents of the students or not. Other clinics acknowledged that income might not be a reliable indicator of "need" for legal resources. At least one clinic assessed need by gathering information on a company's budget rather than revenue, and allowing licensing fees or deferred salaries or expenses to mitigate a higher budget. ${ }^{134}$ Another clinic analyzed funding rather than income, and limited prospective clients to less than $\$ 1$ million in funding rounds. ${ }^{135}$

Cincinnati Law School, and University of Missouri-Kansas City School of Law.

131 Arizona State University Sandra Day O'Connor School of Law's Lisa Foundation Patent Law Clinic's intake form includes a question as to whether the client could otherwise afford the services and asks for a good faith answer to that question. Similarly, Hofstra University Maurice A. Deane School of Law's Entrepreneurship and IP Clinical Practicum's test is "not reasonably able to pay for similar representation;" American University Washington College of Law Glushko-Samuelson IP Clinic's test is "can't afford legal services in the market;" Vanderbilt University Law School's IP and the Arts Clinic's test is "'but for' our free services, would you hire a lawyer to do this work?"

132 Texas A\&M University School of Law Patent Clinic and Trademark Clinic is 300\% of poverty level; University of Washington School of Law's Clinics, University of Detroit Mercy School of Law's International IP Clinic and Thomas Jefferson School of Law's Clinics use $200 \%$ of poverty level; University of Missouri-Kansas City School of Law's IP Clinic uses the median income in the state; Lincoln Law School of San Jose's IP Clinic uses "standard pro bono national requirements;" and University of California Los Angeles School of Law's Patent Law Clinic uses the USPTO standard for micro-entity status (a filing category with set income limits).

133 University of California Los Angeles School of Law's Trademark Clinic uses "under $\$ 1.50 \mathrm{k}$ from all revenue streams," Howard University School of Law's IP and Trademark Clinic uses " $\$ 60 \mathrm{k}$ for individuals and $\$ 100 \mathrm{k}$ for entities," Washington University in St. Louis School of Law's Entrepreneurship and IP Clinic says "pre-revenue only, but social enterprises must be below $\$ 175 \mathrm{k}$," and California Western School of Law's clinic says "\$125k in annual revenues."

134 Benjamin N. Cardozo School of Law's Indie Film Clinic.

135 University of California Hastings School of Law's Startup Legal Garage. 


\section{d. Even though most IP/T clinics do not exclude clients based solely on a rigid income cap, they would argue that their missions are still in the "public interest"}

In summary, our results show that only a minority of IP/T clinics impose a mandatory and consistent income means test on clients. And paradoxically, the clinics that care the most about choosing clients with social missions, or choosing clients that bring a larger policy issue to the forefront or represent a larger class, care the least about an income cap, since some of their clients are medium to large nonprofits. Most IP/T clinics consider a prospective client's ability to pay when evaluating client selection, but ultimately client income is just one of several factors that go into the client selection decision. These clinics seem willing to stretch income restrictions for various reasons, including to make an impact, or to provide a rich and unique experience for students. At least based on conventional wisdom, this may be a difference between the IP/T clinical community and some of the rest of the clinical community. The wider clinical community is known to impose a stricter income means test, especially in light of federal funding requirements or if their clients come primarily from public referral sources.

However, this raises the question of whether IP/T clinics should necessarily impose a means test on their clients. Can the public interest still be served when IP/T clinics counsel clients that do not strictly fall within certain indigent categories? Does the pursuit of pedagogical or vocational missions such as exposing students to new technologies and cutting edge law suffer if the client list is limited in a meanstested way? Is the subject matter handled by IP/T clinics unique such that clinics must work with at least some more affluent clients to guarantee good quality experiences for students?

For now, the survey results imply that a strict means test is not necessary for most IP/T clinics to pursue their missions, and that many IP/T clinics would consider much of the work they do to be both important and in demand, and in the public interest. ${ }^{36}$ These clinics are spurring innovation to help communities, commenting on and im-

136 For example, the University of Notre Dame Law School's IP and Entrepreneurship Clinic describes their work as follows: "The subject matter mix is based in part [on] increased interest in our students in IP law as well as client demand. In addition, our mission, as well as our participation in the USPTO's program, requires that we provide pro bono services for clients that might not otherwise be able to afford counsel. Given the high cost of IP counsel and the potential loss of IP rights during a start-up's initial phase, there is a high demand in this area." More explicitly, the University of Ottawa Faculty of Law's Samuelson-Glushko Canadian Internet Policy and Public Interest Clinic explains: "[We choose clients in order to] [r] espond to pressing public interest issues of the day, and the absence of ability to raise a public interest perspective." 
pacting public policy, and protecting the rights of the individual against larger and more powerful interests.

\section{InNOVATIONS}

\section{A. The IP/T Clinical Community Continues the Tradition of Innovation in Clinical Legal Education}

When the earliest IP/T clinics emerged in the clinical community, the subject matter seemed distant from the legal issues most common in clinical settings. After all, the legal services movement inspired the establishment of clinics where law students typically worked in practices areas directly impacting the lives of poor or otherwise disadvantaged people. 137

Innovations in legal education and experiments in experiential learning have dotted the law school landscape since the early 20th century. ${ }^{138}$ The $1960-70$ s ushered in the true first wave of what we have come to know as clinical legal education. This wave was typified by volunteer, non-credit legal dispensaries or legal aid bureaus providing hands-on opportunities for law students to learn and practice lawyering skills. Born in the civil rights era, access to the legal system and social justice concerns were essential components of the work. ${ }^{139}$ In addition, as the clinical community continued to grow and mature, a pedagogy emerged centered on creating experiential spaces to allow law students to develop self-conscious, reflective, self-critical approach to law and lawyering. In the 1980's, clinical legal education advocates worked on legitimizing and expanding its place in the academy. ${ }^{140}$ This second wave also saw the growth of external funding from foundations, alumni, and state and federal government. The community of early clinics based primarily on a legal services model also began to welcome clinics working in more specialized practice areas.

The community has continued to mature and innovate, and now the third wave of clinical legal education is well underway. After decades of resistance to this form of education, the legal academy is now generally in agreement that experiential learning must be a part of the core curriculum to ensure that students have sufficient opportunities

137 See Ashar, supra, note 11, at 356 (writing that one of clinic's main functions is that of "service provider of last resort to poor people").

138 See generally WILson, supra note 22 (providing a thorough and fascinating history of early experiential legal education).

139 See Kotkin \& Rivkin, supra note 27, at 199 (stating that most clinicians "who formed the vanguard of clinical education in the 1970s and 1980s came to law school teaching from public interest/legal services/ public defender backgrounds").

140 See Margaret Martin Barry et al., Clinical Education for This Millennium: The Third Wave, 7 Clin. L. Rev. 1, (2000). 
to develop essential lawyering skills needed as twenty-first century practitioners. This pedagogy across the law school curriculum has evolved to embrace more experiential learning opportunities in externships, practicums, and clinical programs, as well as in the teaching of doctrine. The IP/T clinical community is very much a part of this newest wave of clinical legal education.

As the survey data suggests, many of the IP/T clinics were born out of this trend recognizing a modern practitioner is one with practice-ready lawyering skills. But as part of the clinical tradition and generally housed within existing clinical programs, these new clinics have largely followed in the footsteps of the pioneers of the first volunteer legal dispensaries and legal aid bureaus. While this burgeoning IP/T clinical community is quite varied in terms of make-up, mission, and approach, many clinics continue the tradition of providing access to pro bono legal services in the intellectual property and technology fields. Defendants of limited means sued for alleged trademark, patent, or copyright infringement may well have winning arguments, but are unable to defend their claim without proper counsel. ${ }^{141}$ For individuals, nonprofits, community organizations and small-business clients of limited means, IP rights offer critical pieces of their path to success and growth and are a vital component to achieving economic justice. ${ }^{142}$ In addition, consumer and civil liberties concerns have all too often been overlooked in the policy struggles of the emerging digital world due to the lack of pro bono legal assistance and expertise in these fields. This new clinical community gives voice to the rights of individuals and the disenfranchised in policy struggles involving wellfunded and powerful corporate interests or overreaching governmental regulation. IP/T clinics also fought for their own student practice rule to incorporate traditional clinical pedagogy in its new practice area. ${ }^{143}$

As the IP/T clinical community continues to grow in numbers, it also has continued to innovate and transform clinical pedagogy to both fit into and challenge the status quo of the clinical community. The survey data demonstrates that IP/T clinics are employing unusual and innovate ways to teach students. These innovations are born of the very same forces that forged the IP/T clinics themselves.

141 See Reese, supra note 25 at 915.

142 See Pantin, supra note 28, at 199.

143 See Wallace J. Mlyniec \& Haley D. Etchison, Conceptualizing Student Practice for the 21st Century: Educational and Ethical Considerations in Modernizing the District of Columbia Student Practice Rules, 28 GEo. J. Legal Ethics 207 (2015); see generally Fan, supra note 17. 


\section{B. The Innovations Rethink Structure, Collaboration, and Subject Matter}

\section{IP/T clinics are experimenting with ways to reach more clients or more clinic students through leveraging the use of the local private bar or new technologies.}

IP/T clinics are experimenting with structures that tap into the expertise of the local private bar to amplify the reach of the clinic. For example, certain clinics ask local lawyers to act as primary supervisors of students, with the clinic director overseeing the whole program..$^{144}$ This allows the clinic to serve not only more clients, but also more students each semester. In addition, other clinics seek out specific expertise that complements the strengths of the faculty supervisor so that students can take on new subject matter than they could have had they had to rely on one supervisor. The use of private practitioners can broaden the clinic's capabilities. ${ }^{145}$

Perhaps not surprisingly, IP/T clinics have also employed technology in a variety of ways and on a variety of levels to increase reach and efficiency. As a simple example, many clinics use technology for internal purposes, for example to streamline onboarding. ${ }^{146}$ Other clinics use technology to enhance their ability to counsel remote clients. ${ }^{147}$ And as an extreme example of how IP/T clinics are using technology to enhance their structure to respond to changing needs, at

144 For example, University of California Hastings School of Law's Startup Legal Garage uses supervising attorneys to scale the course so that sixty students can take the clinic each year, which they state "has been a key factor in our success." Similarly, University of Washington School of Law's Entrepreneurial Law Clinic teams law and business students with pro bono attorneys and business advisors to supervise the early stage legal and business counseling work. Also Mitchell Hamline School of Law's IP Clinic leverages the use of the private bar, stating "I think the blend of private practitioners with in-house counsel provides a positive experience for the students." And York University Osgoode Hall Law School's IP Osgoode Innovation Clinic uses several supervising lawyers, who "play a critical role as they determine the scope of issues that we can assist with and the work that our students can perform."

145 The University of Missouri School of Law's Entrepreneurship Legal Clinic, which incorporates private practitioners as supervisors, reports: "Our collaborations with supporting law firms have permitted us to offer specialty services to clients." At the University of Maryland Francis King Carey School of Law's IP and Entrepreneurship Clinic, the use of a clinical law instructor as well as two adjuncts with different backgrounds "allow[s] the clinic to work on a broader range of patent projects."

146 As a good example, California Western School of Law's New Media Rights Clinic has harnessed technology for their onboarding process, ensuring that student accounts are set up, paperwork is signed, and students are ready to start client work from the first day. The Clinic says this efficiency is critical to set the tone for students to go through a relatively high volume of clients, which the clinic says is key for student learning in that clinic.

147 California Western School of Law's Trademark Clinic describes itself as a "virtual clinic," where files, forms, a practice guide, and the docket are located in the cloud, which it says allows the clinic to take on clients throughout the country. 
least one clinic uses technology to connect remote supervisors or even incorporate remote students. ${ }^{148}$ Besides enabling working students to take the clinic, technology gives such a clinic flexibility to "use volunteers from nearly anywhere across the US, provide services to clients across the nation, and give students a very real life scenario of working with a variety of professionals from around the world." 149

\section{IP/T clinics are incorporating methods to teach client development and administrative skills}

Several clinics are experimenting with ways to expose students to skills helpful to the business of running a law firm. This may be in response to a shifting job market where increasing numbers of students must engage in firm management and client development as they join small to medium-sized firms or start their own practice upon graduation.

For example, traditionally, the faculty chooses clients before the semester begins, allowing the students to start working immediately and allowing the professor to retain control over what type of work or lessons will be presented through the client work. However, some IP/ $\mathrm{T}$ clinics are instead engaging students to various degrees in client development. In some situations, faculty still prescreens possible clients, but allows the clinic students to evaluate, discuss and decide as a group which clients among several choices the clinic would like to represent. ${ }^{150}$ Other clinics give students even more ownership over client choice and client development by tasking the students with actually finding and recruiting clients. Two such clinics require students to attend community networking events and meetings of student-run entrepreneurial groups on campus in order to introduce the clinic to attendees and drive potential work to the clinic. ${ }^{151}$ This recruiting function is part of a larger mission to help students learn to manage and run a law office.

Although allowing students to play a role in client development

148 Lincoln University of San Jose Law School's IP Clinic relies heavily on cloud-based resources and collaboration systems, including a digital classroom called NewRow. Since many of Lincoln's students have full time jobs outside the law school during the day, only some of the clinic's seminar sessions are run live at the school. Supervisory sessions also happen remotely.

149 Lincoln University of San Jose School of Law.

150 Such clinics include Harvard University School of Law's Cyberlaw Clinic, University of California Irvine School of Law's IP, Arts, and Technology Clinic, Arizona State University Sandra Day O'Connor School of Law's Lisa Foundation Patent Law Clinic, Benjamin N. Cardozo School of Law's Tech Startup Clinic, and Northeastern University School of Law's IP Co-lab.

151 For example, University of Miami's Startup Practicum and Northeastern University's IP Co-lab. 
might delay the start of the actual client work, for these clinics, the lessons in administration are an important part of the pedagogy. The hope is that clinic graduates would be able to distinguish themselves after graduation if they already have experience cultivating their own clients. The clinic director can maintain control over client selection somewhat by imposing parameters on the client selection, while still allowing the students discretion to choose among options. By allowing them autonomy, the students may also be more invested in the clients they themselves develop or choose. And although occasionally students may choose clients that the clinician may know will be more difficult to counsel than others, the resulting lessons learned about subject matter, personalities, circumstances and logistics are also valuable client development and firm management skills.

Beyond engaging students in client development, some clinics also are teaching students to navigate internal corporate structure. For example, some clinics adopt a structure to mimic the typical hierarchy of a law firm. ${ }^{152}$ At one clinic, second semester clinic students play the role of "senior associates" and assume some supervisory authority over new "junior associate" clinic students. Not only does this setup give the students an opportunity to practice giving feedback in the role of supervisor and accepting comments from a peer as a "supervisee," but the clinic director has noticed that the structure has increased clinic efficiency and "throughput."153 Another clinic holds seminar classes at the clinical supervisor's law firm to emphasize the message that the clinic is really a law firm. ${ }^{154}$ And other clinics purposefully ask students to take on a sizeable amount of clinic administrative responsibilities to introduce them to firm back office administration. ${ }^{155}$

\section{IP/T clinics are experimenting with credit allocation and structure to accommodate student preferences}

Through innovating in terms of credit allocations, IP/T clinics may be making it easier or more attractive for students to have a clinical experience. The survey revealed that there is wide variation among credit offerings across the community, although in general the credit allocation skews low.

152 Including Indiana University Bloomington Maurer School of Law's IP Law Clinic, Chicago-Kent College of Law's IP Law Clinic, and California Western School of Law's Trademark Clinic.

153 Indiana University Bloomington Maurer School of Law's IP Law Clinic.

154 Chicago-Kent College of Law's IP Law Clinic.

155 Northeastern University and University of Miami are standouts in this category. Northeastern University even leaves it up to the students to decide how to staff client assignments appropriately. 
How Many Credits Is Your Chinic?

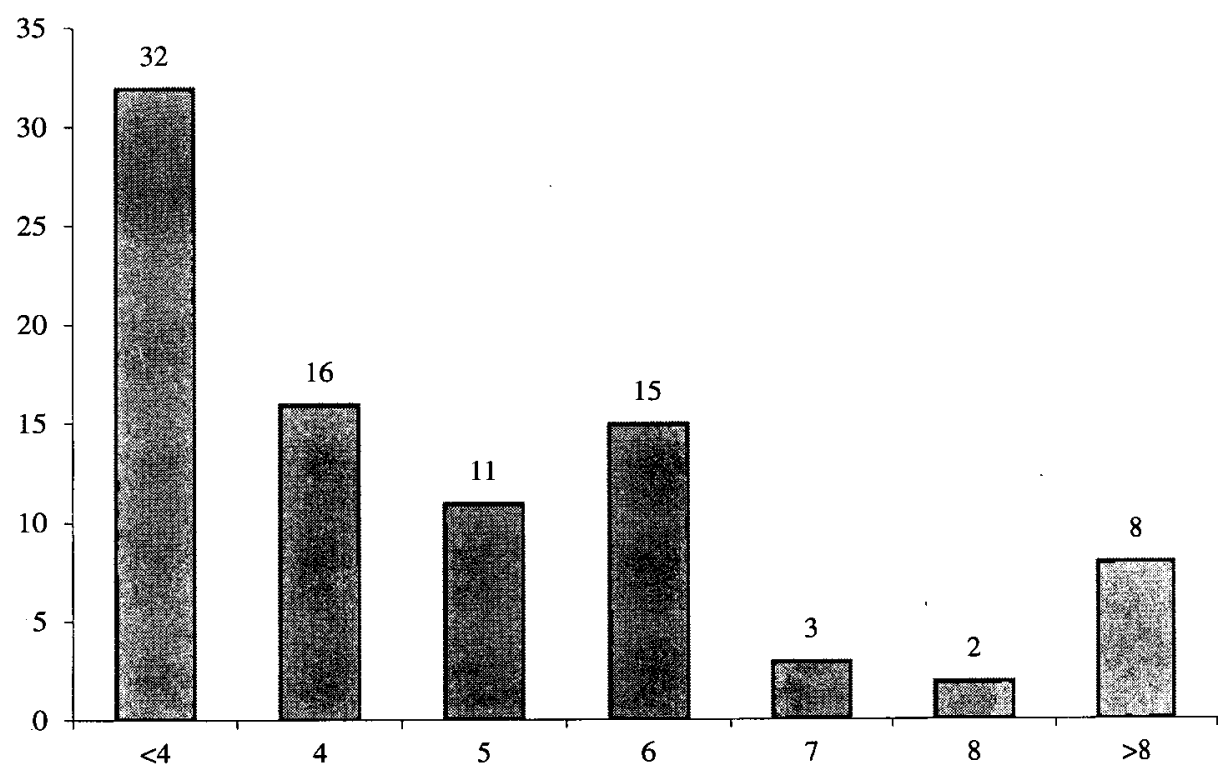

At the one end of the range, almost half of the IP/T clinics ${ }^{156}$ offer at least an option to take the clinic for fewer than 4 credits. ${ }^{157}$ Interestingly, most of the clinics that primarily handle rights acquisition fall into this $<4$ category, 158 although that is not the only type of IP/T clinics that grants fewer than 4 credits. ${ }^{159}$ On the other end of the range, very few clinics grant more than 8 credits. ${ }^{160}$ No one category of clinic makes up the majority of this high credit group, although several of

15632 out of 65 question respondents, or $49 \%$.

157 We did not ask questions to normalize credits across law schools. Also, we allowed people to designate more than one answer if they offered several different credit options.

158 When IP rights acquisition clinics offer 4 credits or more, they still do not offer many more than 4: for example, John Marshall Law School, Howard University Law School, and Lincoln University of San Jose Law School offer their IP/T clinics for exactly 4 credits; Mitchell Hamline School of Law offers options for 4 credits or for 6 credits; and University of North Carolina Chapel Hill School of Law offers 6 credits.

159 For example, the Hofstra Law School Entrepreneurship \& Intellectual Property Practicum, the Santa Clara University School of Law Entrepreneurs' Law Clinic, the University of Detroit Mercy School of Law International Intellectual Property Law Clinic, and the University of Florida Levin College of Law Entrepreneurship Law Practicum all are offered for fewer than 4 credits.

160 There are eight clinics in this category: American University Washington College of Law's Glushko-Samuelson IP Clinic, Stanford University Law School's Juelsgaard IP and Innovation Clinic, University of Washington School of Law (both the Entrepreneurship Law Clinic and Technology Law and Public Policy Clinic); Boston University School of Law-Massachusetts Institute of Technology's Entrepreneurship and IP Clinic; Suffolk University Law School's IP and Entrepreneurship Clinic; University of California Hastings School of Law's Startup Legal Garage; and Case Western Reserve School of Law's IP Venture Clinic. 
those clinics are either full year clinics or from schools on the quarter system that require students to take no other contemporaneous courses. About a quarter of responding IP/T clinics offer the option to take the course for exactly four credits, ${ }^{161}$ and an almost equal amount offer exactly six credits. ${ }^{162}$ Therefore, almost $75 \%$ of the IP/T clinical community grants 4 credits or less to at least a portion of its class. ${ }^{163}$

How are IP/T clinics able to keep this credit allocation so low and still provide a comprehensive experience to students? One answer might be to require that students already come to the clinic with some knowledge. Although most IP/T clinics have a mandatory contemporaneous seminar accompanying the client work, ${ }^{164}$ with mandatory prerequisite courses, less of that seminar may need to be focused on teaching students necessary substantive law or lawyering skills. Clinics vary in their requirements, depending on their orientation. Some strongly recommend a course in start-up law; ${ }^{165}$ in others that specialize in IP rights acquisition, students have to have taken prior courses in both substantive patent or trademark law and in drafting. ${ }^{166}$ Other clinics mandate a co-requisite class, which separately teaches an aspect of counseling. ${ }^{167}$ And many clinics require that students take at least an introductory course in IP law. ${ }^{168}$

Although under the prerequisite model students end up spending the same amount of time overall in class, perhaps moving some of the subject matter out of the clinic gives students more flexibility with their schedule, allowing them to take what would have been a seven or eight credit clinic class over two or more semesters. Maximizing student flexibility and ability to diversify experience in any one semester also may be behind offering differing credit options even within the same class of students. Some clinics allow students to be as involved in the clinic as their schedules will allow, within an acceptable range, for a commensurate number of credits. ${ }^{169}$ Clinics also allow

\footnotetext{
16116 out of 65 respondents, or $24.6 \%$

16215 out of 65 respondents, or $23.1 \%$

16348 out of 65 respondents, or $73.8 \%$

16465 out of 68 respondents, or $95.6 \%$.

165 For example, Benjamin N. Cardozo School of Law's Tech Startup Clinic requires, and University of Miami School of Law's Startup Practicum strongly recommends, that clinic-enrolled students take a separate course focused on start-up law before enrolling.

166 Ave Maria School of Law's Patent Law Clinic, for example, requires that students in its patent prosecution clinic take both patent law and patent drafting before enrolling.

167 At Benjamin N. Cardozo School of Law's Tech Startup Clinic, students take the lawyering skills seminar at the same time as the clinic.

168 For example, Howard University Law School's Trademark Clinic.

169 At Harvard University Law School's Cyberlaw Clinic, as an example, after completing a co-requisite seminar which is worth two credits, students have the option to take the client work aspect of the clinic for either three, four, or five credits, which each corre-
} 
students to continue their client work into an additional second semester, in effect giving them control over how much client work they do in any one semester, even if they want to work with clients for a substantial number of credits. ${ }^{170}$ This second semester may, but does not have to, be for fewer credits than the first semester of client work. ${ }^{171}$

It would be interesting to study whether these innovations make students more likely to commit to taking a clinic, which is usually a time- and effort-intensive experience, especially as many students try to maximize and diversify their law school experience. It would also be interesting to note whether a desire to compete with lower credit offerings like externships and experiential simulation classes helped to drive some of this credit allocation innovation. In any event, since many IP/T clinics are experimenting with credit allocation, future surveys could study the reasons behind the experimentation and any results, as well as if and how different credit allocations may affect the level of complexity or impact of student work.

\section{IP/T clinics are incorporating interdisciplinary lessons into the seminar to better prepare law students to work with new clients as well as professionals from different fields}

Clinics have for many years taught through the philosophy of "client-centered lawyering." By specifically teaching law students to appreciate the often differing mindset of their client, and to orient themselves to counsel keeping that mindset at the forefront, the students become more effective counselors. ${ }^{172}$ IP/T clinics are continuing that tradition, with one additional twist especially relevant to this area of law which may have a lesson for other clinics as well. Not only is it useful to reorient IP/T clinic students in order to help them to better reach their business and technology clients, but also it is useful to train the students in an interdisciplinary way so that they can work with the

sponds to a set number of hours for the semester.

170 At Harvard University Law School's Cyberlaw Clinic, should a clinic student decide to re-enroll for another semester, she may again choose either a three, four, or five credit client work option. At Wayne State University School of Law's Patent Procurement Clinic, students can enroll in the clinic for one semester at 4 credits, and then take an additional semester for another two credits.

171 At Stanford University Law School's Juelsgaard IP and Innovation Clinic, the second quarter can be taken for two to seven credits, depending on the number of hours the student wants to put into client work.

172 For a discussion of the necessity of client-centered lawyering, see generally STEFAN H. Krieger and Richard K. Neumann, Essential Lawyering Skills: Interviewing, Counseling, Negotiation, and Persuasive Fact Analysis (5th ed. 2015); Alicia Alvarez and Paul R. Tremblay, Introduction To Transactional Lawyering PracTICE (2013). 
other professionals they will encounter in the field. The practice of law is becoming increasingly interdisciplinary, and no more so than in the realm of IP and technology, where lawyers consult daily with professionals trained in business, engineering, data, technology, science, and the arts.

Several clinics are meeting that challenge by specifically incorporating business and engineering perspectives into the seminar through interdisciplinary opportunities and unique collaborations. The goal is to help law students to work better with their business, engineering, and creative economy clients, and also to prepare them to consult with other professionals as they deliver their counsel.

Several IP/T clinics advertise themselves as deliberately interdisciplinary. ${ }^{173}$ On the modest end, many clinics incorporate non-legal speakers into the syllabus, or add readings from other disciplines like social sciences, technology, and public policy into the curriculum to spur discussion. ${ }^{174}$ Clinics also encourage students to consult outside non-legal experts on client work. ${ }^{175}$ On the more experimental end, clinics challenge law students to work side by side with students from other disciplines. One way is through simulations and exercises, where students from other schools are guests in the clinic for one or more sessions. ${ }^{176}$ Other clinics pair law students with students from other professional schools and share clients, both to offer the clients multifaceted counsel and to allow the students to experience the perspective, questions, and counsel of a differently-trained professional. ${ }^{177}$ Finally, a surprising number of clinics actually cross-enroll

173 See e.g., the University of Washington School of Law's Entrepreneurship Clinic, Northeastern University School of Law's IP Co-lab, Suffolk University Law School's IP and Entrepreneurship Clinic, and University of Pennsylvania Law School's Detkin IP and Technology Legal Clinic.

174 For example, Northeastern University School of Law's IP Co-lab brings in speakers from the business and engineering schools, and also sends its students out to make presentations on IP at other schools around campus; the University of Arizona College of Law's IP Clinic brings in speakers to handle business law and tax issues; and University of California Irvine School of Law's IP, Arts, and Technology Clinic brings in "social science research, technological processes, policy, etc. — areas outside law - quite often."

175 See e.g., University of California Berkeley School of Law's Samuelson Law, Technology, and Public Policy Clinic.

176 The University of Pennsylvania Law School's Detkin IP and Technology Legal Clinic, for example, pairs law clinic students with students from the engineering school over a patent drafting exercise with the specific goal of exploring legal-technical partnerships. See Cynthia Laury Dahl, Teaching Would-Be IP Lawyers to "Speak Engineer": An Interdisciplinary Module to Teach New Intellectual Property Attorneys to Work Across Disciplines (2015), available at http://scholarship.law.upenn.edu/faculty_scholarship/1562.

177 University of Pennsylvania Law School's Detkin IP and Technology Legal Clinic, Indiana University Bloomington Maurer School of Law's IP Law Clinic, and St. Louis University Law School's Entrepreneurship and Community Development Clinic are examples of clinics that use interdisciplinary teams. At University of Pennsylvania and the Uni- 
students from outside the law school into the clinical seminar for a consistent and heavy dose of interdisciplinary perspective. ${ }^{178}$ It also gives law students a precious opportunity to practice explaining complicated issues particular to law to a non-legal audience, for example obligations under the rules of legal ethics, or details of contract interpretation. And it thoroughly prepares law students to consider their communication style and their approach to better work not only with differently-minded clients, but other professionals throughout their career.

\section{IP/T clinics are experimenting with new alliances with outside groups}

Many IP/T clinics note that official alliances or relationships with specific outside organizations are central to their clinic's success. While perhaps forging alliances with outside organizations is not an innovation specific to IP/T clinics, the nature of the alliances might be. For example, in an IP/T clinic scenario, alliances have included other schools or parts of the university such as the technology transfer office ${ }^{179}$ or even other universities themselves. ${ }^{180}$ Besides providing a steady stream of interesting client work, such alliances can be critical to the clinics' pedagogical missions, in that management and conflicts questions that arise because of the unique structure of the alliance, or interesting ethical issues about confidentiality, privilege and conflicts of interest can be tackled in class every semester. ${ }^{181}$

versity of Washington, the law clinic students can share clients with a team of students from the business school, and at the University of Washington School of Law's Technology and Public Policy Clinic, law clinic students share joint projects with students from the computer science and engineering schools.

178 These clinics engaging in cross enrollment include: Suffolk University Law School's IP and Entrepreneurship Clinic (MBAs); University of Washington School of Law's Entrepreneurial Law Clinic (MBAs), University of Washington School of Law's Technology Law and Public Policy Clinic (Business, Public Policy); University of California Berkeley School of Law's Samuelson Law, Technology and Public Policy Clinic (School of Information and Computer Science, and School of Public Policy/Law joint degree candidates), and University of Colorado Boulder Law School's Samuelson-Glushko Technology Law and Policy Clinic (engineering/telecom/social sciences students).

179 See University of Illinois at Urbana-Champaign College of Law's IP Clinic's relationship with its engineering school's TEC program, and University of Pennsylvania Law School's Detkin IP and Technology Legal Clinic and University of Washington School of Law's Entrepreneurial Law Clinic's alliance with their respective university tech transfer offices.

180 One spectacular example is Boston University Law School's partnership with Massachusetts Institute of Technology, which while being "famous for transgressive innovation, lack[s] a law school." The partnership, called the Entrepreneurship, IP and Cyberlaw Program, has two related but separate clinics that help student entrepreneurs and innovators: the Entrepreneurship and IP Clinic; and the Technology and Cyberlaw Clinic.

181 See Dahl, supra note 113. 
Sometimes the relationships also offer intangible advantages, for example when the clinic resides inside the allied business partner's space. ${ }^{182}$ Sharing a non-legal space with other parties allows the clinic students to experience practicing law in a non-legal environment (not unlike being in house counsel), as well as absorb the pace, needs, vocabulary and issues of their clients firsthand. Such alliances may also allow clinics to work on cutting edge work, as a ready relationship with a state or local government makes it easy to get policy assignments that might not otherwise have sufficient staff or budget to support them. ${ }^{183}$

One of the most innovative and successful alliances is the IP/T clinical community's collaboration with the USPTO. The Law School Certification Program established a student practice rule pilot program at the agency in 2008 that has been expanded in subsequent years. ${ }^{184}$ The program was sparked by a result of a request for student practice in front of the agency by the American University GlushkoSamuelson IP Law Clinic. ${ }^{185}$ Since the early days of clinical legal education, local jurisdictions and federal courts had worked with law school clinical programs to develop robust rules for student practice in the courts. ${ }^{186}$ Over the years, other federal agencies had adopted rules that explicitly permitted law students in legal clinics to practice before them in various capacities. The request noted that as the importance to the economy of trademarks and patents had grown, law school clinical programs had expanded their representation of clients with a demonstrated need for pro bono services in this area.

Given the growing reputation and success of the program, the noted benefits to pro se and low income applicants and the desire by

182 University of Maryland Francis King Carey School of Law's IP and Entrepreneurship Clinic's relationship with the school of engineering and its entrepreneurial arm, the Maryland Technology Enterprise Institute allows the clinic to reside inside of the engineering school's business incubator, thereby allowing students to work not only with, but among startups.

183 University of Washington School of Law's Technology Law and Public Policy Clinic takes advantage of a good relationship with city and state legislators and executive office officials to assume such impactful projects as working with the Chief Privacy Officer of Washington State on legislation creating a state office of privacy and data security, working with legislators to understand Bitcoin and other crypto currencies, and examining the pros and cons of Internet voting. Similarly, Benjamin N. Cardozo School of Law's Tech Startup Clinic's relationship with the New York Attorney General's Office has led to students exploring the impact block chain technology can have on government, in particular digitally authenticated data, like voting, IDs, property registries and other certifications.

184 See generally Fan, supra note 17.

185 See HR 5108 Codifies USPTO Law School Clinic Pilot Program, Am. Univ. Wash. Coll. of Law Samuelson-Glushko IP Clinic, (Dec. 5, 2014), https://ipclinic.org/2014/ 12/05/hr-5108-codifies-uspto-law-school-clinic-pilot-program/.

186 See Mlyniec \& Etchison, supra note 143. 
many law schools to have their students participate, Congress enacted legislation in December of 2014 authorizing the program to continue for ten years and opening it to all law school clinics meeting certain criteria. ${ }^{187}$ Our survey data shows that the majority of clinics doing prosecution work for more than $80 \%$ of their clinic caseload were founded after the initiation of the pilot program and most have come online after the program was expanded. ${ }^{188}$ The alliance between the USPTO and the participating law school clinics has continued to expand beyond client referrals with new collaborations including monthly conference calls and an annual conference at the USPTO for participating clinic students.

\section{IP/T clinics are experimenting with collaboration with other legal clinics - both IP and non-IP - within and outside the home university}

Besides collaborating with outside groups, IP/T clinics are also looking within to experiment with other clinical programs to broaden and enrich the student, and sometimes the client, experience. Such cross-clinic collaboration can not only provide additional services to the client, but when two clinics with different disciplines collaborate, it also has the potential to introduce students to new legal concepts. Such collaborations also model the real practice scenario where different firm departments or different firms altogether work together to serve the same client.

In their simplest form, collaborations can present as referral networks. Many IP/T clinics regularly refer clients to other IP/T clinics outside the university, for example when dockets are full or when a client needs counsel in a specialty that another clinic has handled before. Several IP/T clinics also have referral relationships with entrepreneurship or community development clinics either within their own schools ${ }^{189}$ and/or at other law schools that might not have their own IP clinic. ${ }^{190}$

IP/T clinics also collaborate with other clinics within the same program to gain an additional perspective. Some are experimenting

\footnotetext{
187 See Act of Dec. 16, 2014, Pub. L. No. 113-227, 128 Stat. 2115 (USPTO Law School Clinic Certification Program).

188 Of the 16 clinics that do $80 \%$ or more rights acquisition work, only 2 clinics were founded before 2008, when the pilot program began, and 6 of the clinics came online in 2013/2014 at the time of the first expansion.

189 For example, the University of Akron Law School's Trademark Clinic takes referrals from the SEED clinic also at Akron, which helps clients with their more general corporate needs.

190 For example, Indiana University Bloomington Maurer School of Law's IP Law Clinic takes referrals and questions from the entrepreneurial support service at Purdue University and the University of Southern Indiana.
} 
with program-wide joint case rounds, ${ }^{191}$ and others cite their shared office space, staff and computer drives as helpful to encourage questions across clinics or to make referrals, similar to departments in the same law firm. ${ }^{192}$ IP/T clinics also take advantage of each other's specific expertise when clients have questions on a discrete issue of law. ${ }^{193}$ Finally, besides using other clinics as referral sources, sounding boards, or outside experts, a few. clinics have taken on the role of co-counsel with another clinic, either each working on joint client work or collaborating on a policy or other project. ${ }^{194}$

Since collaboration can benefit clients and students, as well as build comradery among the IP/T clinical community, cross-clinic and cross-university collaboration can present great opportunities, particularly as the community continues to grow.

\section{CONCLUSION}

Clinical legal education provides a powerful methodology for students to learn about the complex relationships between intellectual property law theory, policy and practice. Live client representation allows students to encounter the experiences of clients who seek protection or clients who feel the legal regimes of intellectual property impinging on their ability to engage in entrepreneurship, innovation and creative and culturally significant contributions to the community. Our survey results demonstrate that IP/T clinics are to a large extent

191 Stanford University's, American University's, and Vanderbilt University's clinics take part in departmental case rounds. Topics of common interest include client engagement and case management.

192 For example, at Thomas Jefferson School of Law, three separate IP Clinics all operate like departments in the same law firm within a larger umbrella of a small business clinic, with shared space, staff and computer drives.

193 Several IP/T clinics for example have reached out to California Western School of Law's New Media Rights Clinic as experts when clients have very specific questions about copyright.

194 The American University Washington College of Law's Glushko-Samuelson IP Clinic for example, has teamed up with the George Washington University's Small Business Clinic to hold "pop-up clinics," where students offer "office-hour" advice in mixed teams twice a year for the Washington Area Lawyers for the Arts. As another model, the University of New Hampshire School of Law's IP and Transaction Clinic has held joint case rounds with the clinic at Suffolk University Law School's IP and Entrepreneurship Clinic. The Harvard University's Cyberlaw Clinic reached out to the University of Pennsylvania Law School's Detkin IP and Technology Legal Clinic to act as "local counsel" for a client project, advising on Pennsylvania state law since the client was located in-state. California Western's New Media Rights Clinic and University of California Irvine's IP, Arts, and Technology Clinic have worked together on $\S 1201$ anti-circumvention copyright issues by filing a joint reply and also collaborated on a hearing to get documentary filmmakers a $\S 1201$ exemption under the DMCA. And the University of Colorado Boulder Law School, American University Washington College of Law and Suffolk University School of Law's clinics have collaborated on trademark bullying advocacy. 
modelled on the clinic tradition in that they help students develop as lawyers through reflection, theory and practice. True to the goals of clinical theory and pedagogy, students can come to understand the law and their roles as lawyers as they work through their responses to the interests of their clients and the relationship to IP and technology doctrine and the varied public interest dimensions in these representations. There are "public interests" embedded in every issue and subject matter in law (and in every kind of case or project), and it is up to the clinical teacher to unearth those dimensions and to endow students with the capacity to work through the professional identity questions spotlighted in the Carnegie Report's third apprenticeship. Clinic students in IP/T clinics should be led to question their responsibility to their client, to society, as well as to those who might be disadvantaged by their legal work.

There is legitimate concern in the clinical community today that given the ABA experiential credit requirements, less costly law school offerings will replace more expensive in-house and live client clinics. There is no doubt that clinics face an increasing battle for student attention not only against externships, simulation courses and practicums but also against law school journals and programs, as well as jobs and pro bono opportunities. Others have noted that generational shifts within the clinical faculty may create uncertainty about the legacy of the social and political vision of the very first clinics. Some question if in this third wave of clinical legal education we risk losing sight of the need to train ethical, principled and skilled practitioners who care about ensuring access to justice in all its forms.

But as we have seen through the results of our survey, the IP/T clinics, while born at a different time and from different environmental influences than the first waves of clinical legal education, are similarly steeped in a desire to serve the public interest, either by providing legal services to the underserved, or choosing clients to maximize social justice impact through litigation and policy advocacy. In fact, IP/T clinics have sparked a response from the private bar and federal government in demonstrating the need for and effectiveness of pro bono practice and advocacy in these fields. And although these clinics are taking clinical legal education in exciting new directions, some of these new directions may help the clinical community as a whole to remain vibrant and relevant in the minds of law schools and students. IP/T clinics have been fortunate, in that all report that that student demand for these clinics remains high. The subject matter they explore is central to both private and public sector practice. Like all clinicians, the IP/T community should be active and engaged partners in the continuing process of curricular reform that has been mov- 
ing the legal academy towards teaching the full range of skills, doctrine and values. The new IP/T clinics can also serve as a model for how new members of the clinical community can be innovative, valuable and exciting to students, while at the same time remaining faithful to the founding mission, theory and pedagogy of clinical legal education. 
Appendix A

Clinics surveyed:

American University Washington College of Law Glushko-Samuelson Intellectual Property Law Clinic

Arizona State University Sandra Day O'Connor School of Law Lisa Foundation Patent Law Clinic

Ave Maria School of Law Patent Law Clinic

Benjamin N. Cardozo School of Law Indie Film Clinic

Benjamin N. Cardozo School of Law Tech Startup Clinic

Boston College Law School Entrepreneurship \& Innovation Clinic

Boston University School of Law Entrepreneurship \& Intellectual

Property Law Clinic

Boston University School of Law Technology \& Cyberlaw Clinic

California Western School of Law New Media Rights Clinic

California Western School of Law Trademark Clinic

Case Western Reserve University School of Law Intellectual Property

Venture Clinic

Chicago-Kent School of Law Intellectual Property Law Clinic

DePaul University College of Law Technology \& Intellectual Property Clinic

Fordham University School of Law Samuelson-Glushko Intellectual Property and Information Law Clinic

George Mason University Antonin Scalia Law School Legal Clinic -

Practical Preparation of Patent Applications

Georgetown University Law Center Communications and Technology

Law Clinic

Harvard University Law School Berkman Klein Center for Internet \& Society's Cyberlaw Clinic

Hofstra University Maurice A. Deane School of Law Entrepreneurship \& IP Clinical Practicum

Howard University School of Law Intellectual Property Law Clinic

Indiana University Bloomington Maurer School of Law Intellectual

Property Law Clinic

The John Marshall Law School Trademark Clinic

Lincoln Law School of San Jose Intellectual Property Clinic

Mitchell Hamline College of Law Intellectual Property Clinic

New York University School of Law Technology Law \& Policy Clinic

North Carolina Central University School of Law Trademark Legal

Clinic

Northeastern University School of Law IP Co-lab

Penn State Law Intellectual Property Clinic

Rutgers University Law School Intellectual Property Law Clinic 
St. Louis University School of Law Entrepreneurship \& Community Development

Santa Clara University School of Law Entrepreneurs' Law Clinic

Southern Methodist University Dedman School of Law Patent Clinic Stanford University Law School Juelsgaard Intellectual Property \& Innovation Clinic

Suffolk University Law School Intellectual Property and Entrepreneurship Clinic

Texas A\&M University School of Law Intellectual Property and Technology Law Clinic

Thomas Jefferson School of Law Trademark Clinic

Thomas Jefferson School of Law Patent Clinic

Thomas Jefferson School of Law Art \& Entertainment Law Project

University of Akron Law School Trademark Clinic

University of Arizona James E. Rodgers College of Law Intellectual Property and Entrepreneurship Clinic

University of California Berkeley School of Law Samuelson Law, Technology \& Public Policy Clinic

University of California Hastings College of Law Startup Legal Garage

University of California Irvine School of Law Intellectual Property, Arts, \& Technology Clinic

University of California Los Angeles School of Law Trademark Clinic University of California Los Angeles School of Law Patent Law Clinic University of Cincinnati College of Law Patent \& Trademark Clinic University of Colorado Boulder Law School Samuelson-Glushko Technology Law \& Policy Clinic

University of Connecticut School of Law IP Law Clinic

University of Dayton School of Law Intellectual Property Law Clinic University of Detroit Mercy School of Law International Intellectual Property Law Clinic

University of Florida Levin College of Law Entrepreneurship Law Practicum

University of Illinois at Urbana-Champaign College of Law Intellectual Property Clinic

University of Maryland Francis King Carey School of Law Intellectual Property Law Clinic

University of Miami School of Law Startup Practicum

University of Missouri-Kansas City School of Law Intellectual Property Clinic

University of Missouri School of Law Entrepreneurship Legal Clinic University of New Hampshire School of Law Intellectual Property and Transaction Clinic 
University of North Carolina Chapel Hill School of Law Intellectual Property Clinic

University of Notre Dame Law School Intellectual Property and Entrepreneurship Clinic

University of Ottawa Faculty of Law Samuelson-Glushko Canadian Internet Policy \& Public Interest Clinic

University of Pennsylvania Law School Detkin Intellectual Property \& Technology Legal Clinic

University of Puerto Rico School of Law Intellectual Property \& Entrepreneurship Clinic

University of Richmond School of Law Intellectual Property \& Transactional Law Clinic

University of San Diego School of Law IP Externship

University of Southern California Gould School of Law Intellectual Property \& Technology Law Clinic

University of Washington School of Law Entrepreneurial Law Clinic

University of Washington School of Law Technology Law \& Public Policy Clinic

Vanderbilt University Law School Intellectual Property \& the Arts Clinic

Washington University in St. Louis School of Law Entrepreneurship \& Intellectual Property Clinic

Wayne State University Law School Patent Procurement Clinic

Yale University Law School Media Freedom and Information Access Clinic

York University Osgoode Hall Law School IP Osgoode Innovation Clinic

Clinics from which we were unable to gather information:

University of Puerto Rico Law School New Technologies, IP and Society Clinic

George Mason University Antonin Scalia Law School Arts \& Entertainment Advocacy Clinic

New York Law School PTO Patent Clinic and PTO Trademark Clinic Southern Methodist University Dedman School of Law Small Business and Trademark Clinic

South Texas College of Law Houston Patent Clinic and Trademark Clinic

University of Buffalo School of Law Civil Liberties and Transparency Clinic

University of California Los Angeles Documentary Film Clinic

Seattle University School of Law Ronald A. Peterson Trademark Law Clinic 
University of Virginia School of Law Patent \& Licensing Clinic University of San Francisco School of Law Internet \& Intellectual Property Justice Clinic

New clinics coming online:

(2019) Georgetown intellectual property clinic (2019-2020) Three new/refunded clinics at the University of North Carolina - Chapel Hill School of Law, including a for-profit-ventures clinic, an intellectual property clinic, and the existing Community Development Law Clinic 
